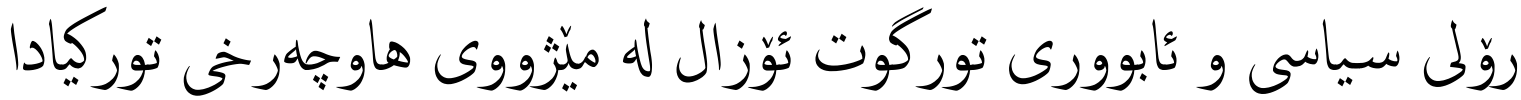 ثامانج حسن أحمد
}

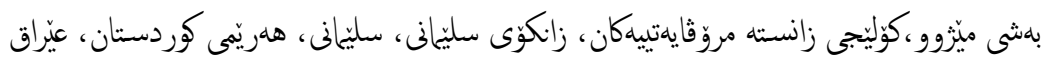

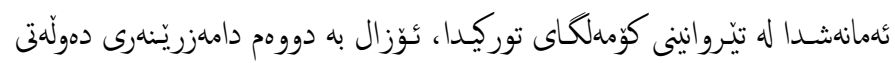

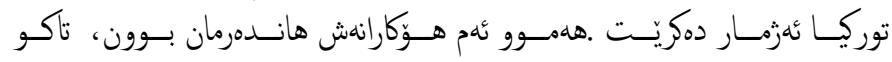

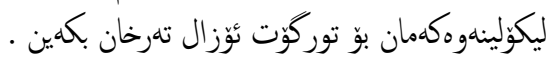

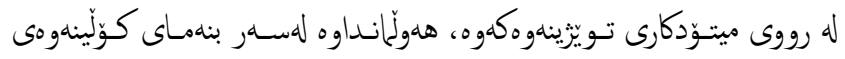

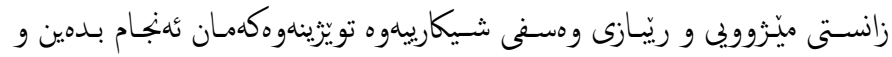

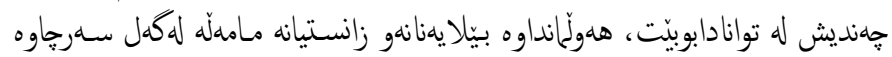

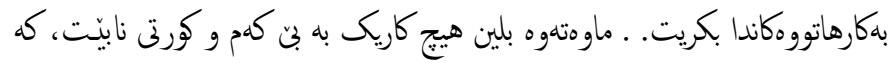

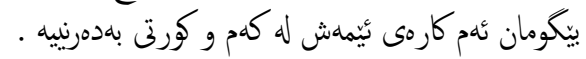

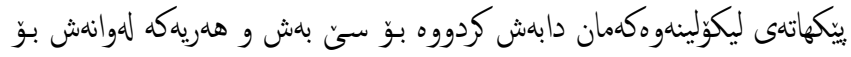

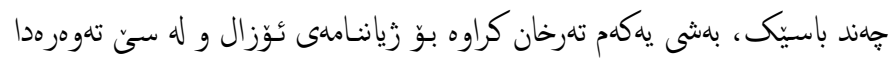

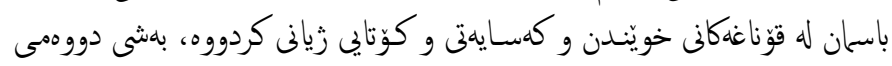

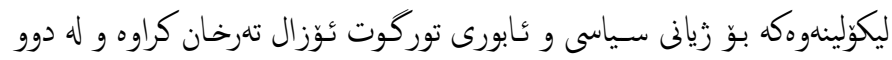

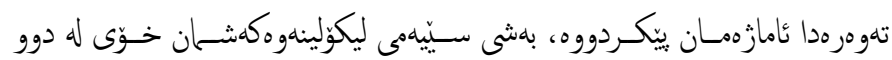

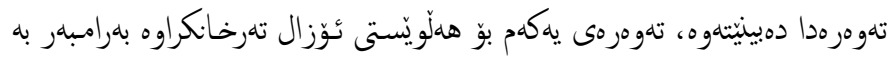

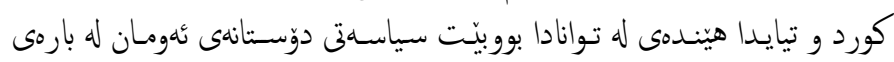

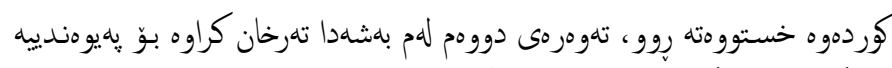

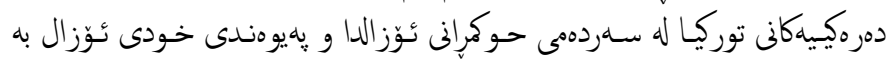

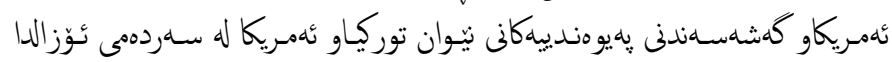

$$
\text { خراوهته رووو. }
$$

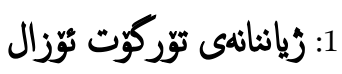

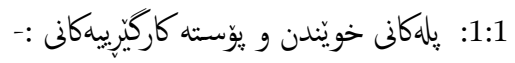

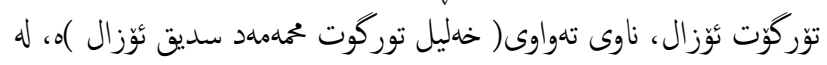

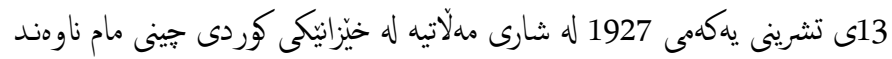

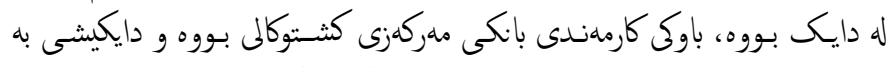

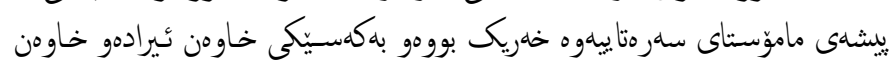

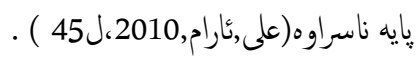

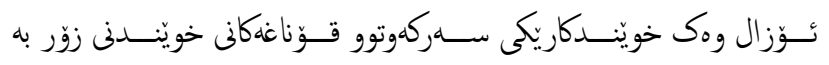

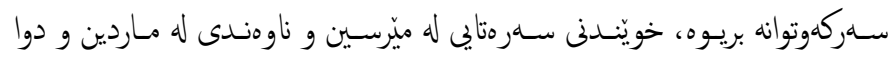

\section{يوختهى تويّرينهوهك}

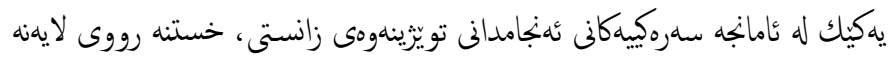

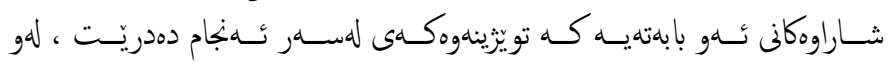

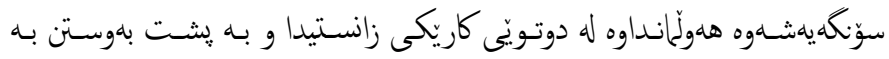

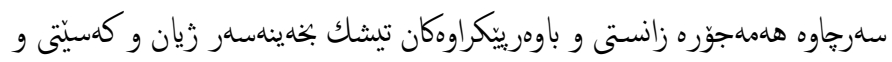

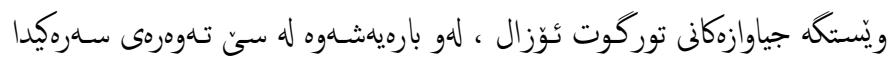

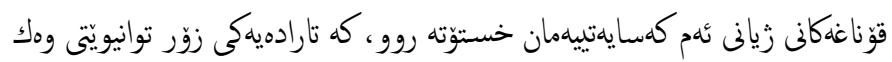

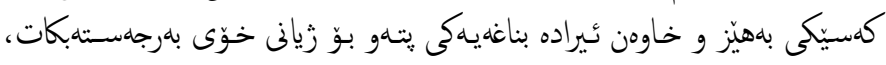

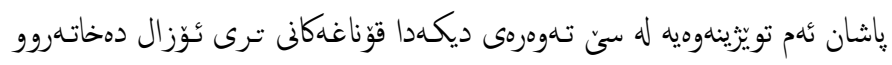

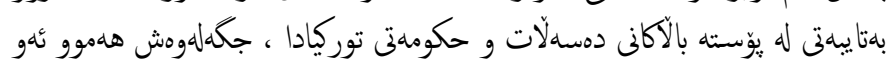

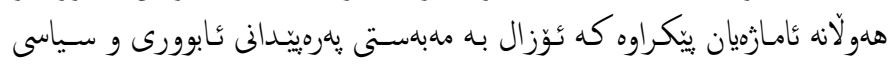

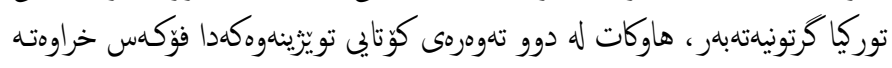

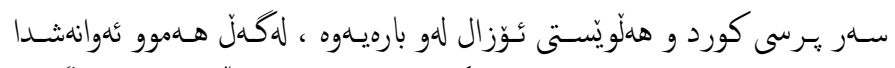

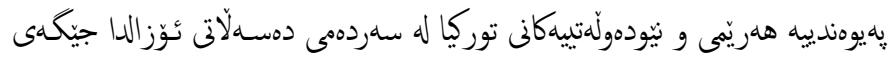

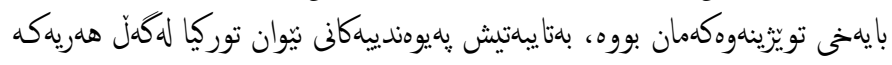

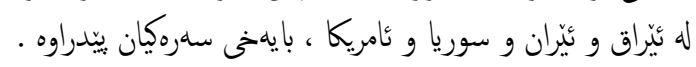

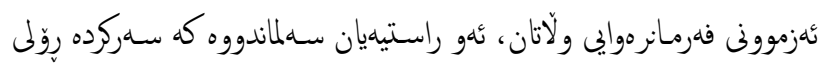

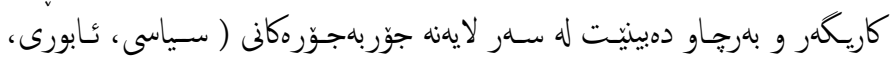

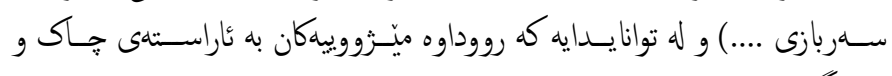

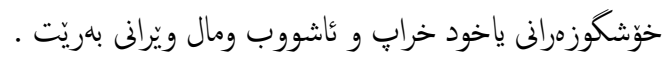

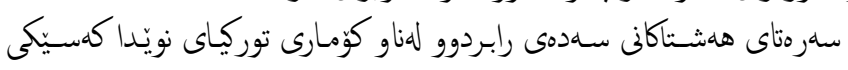

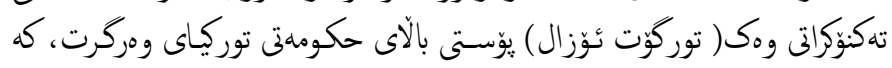

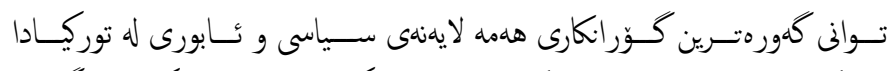

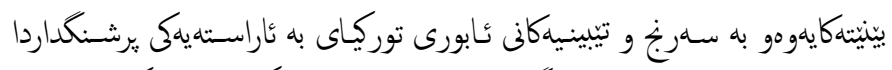

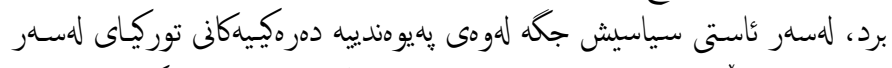

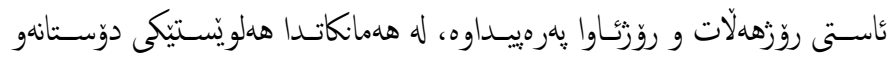

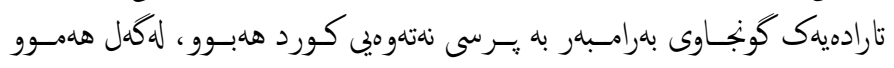


TurgutÖzal Facts: ( لايهنانه خوّش بوو، كه لهو هولّه تيروَرستيليهوه كلابوون ) ( (2010،biography

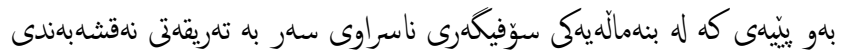

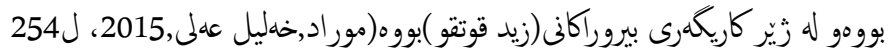

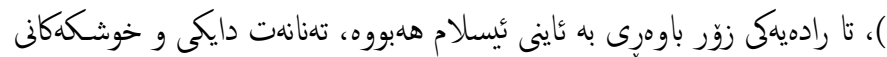

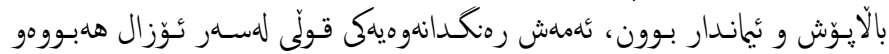

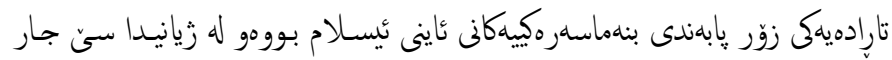

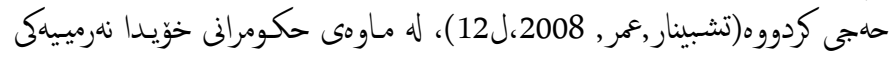

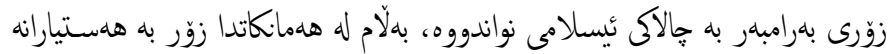

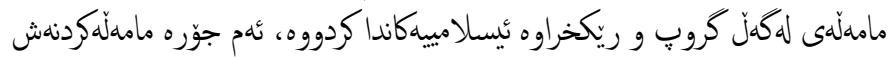

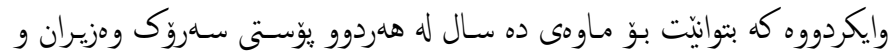

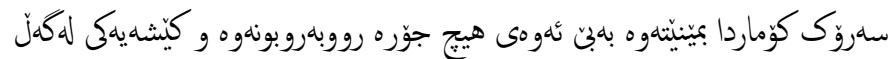

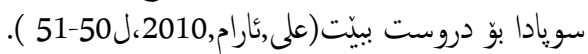

\section{3:2:1}

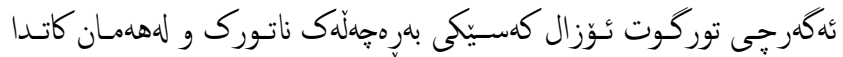

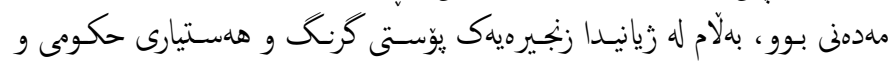

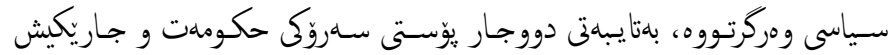

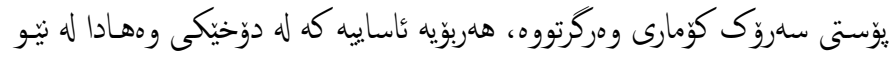

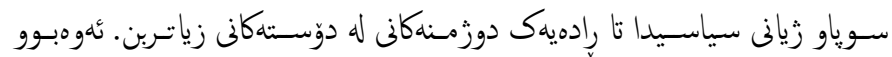

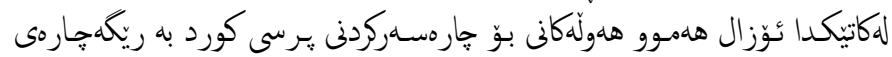

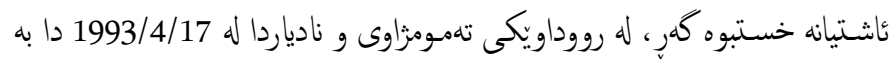

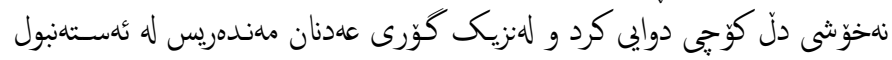

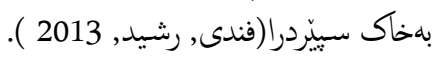

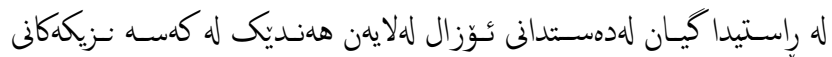

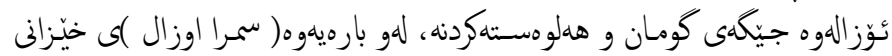

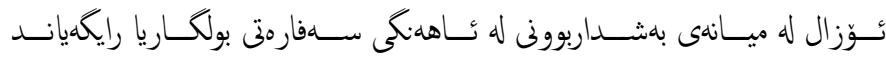

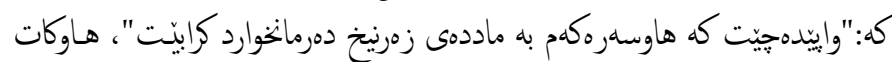

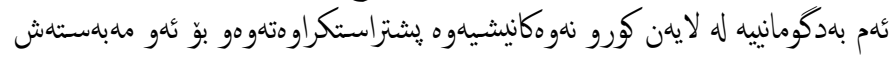

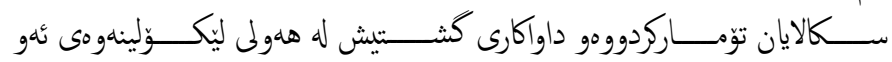

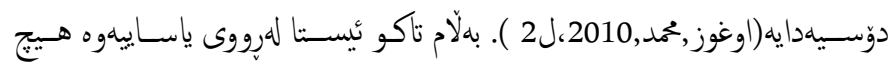

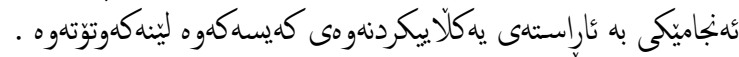

\section{2: 2: زيانى سياسى و ثابورى توركوت ثوزال

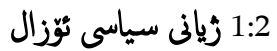

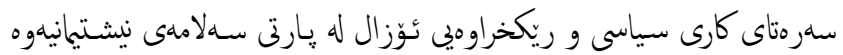

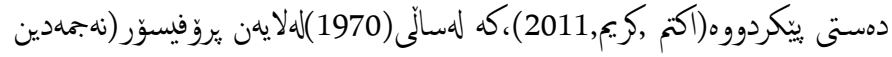

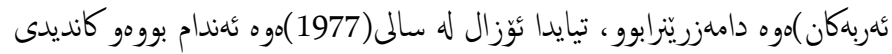

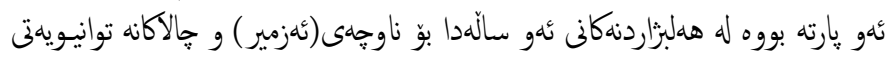

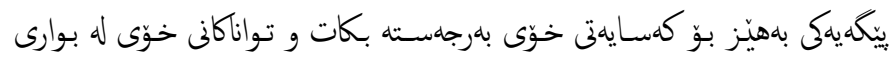

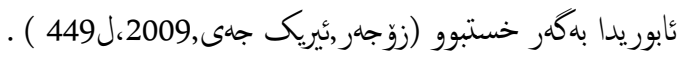

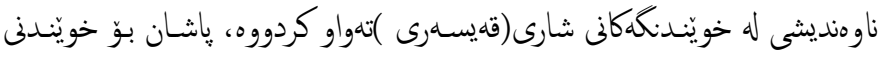

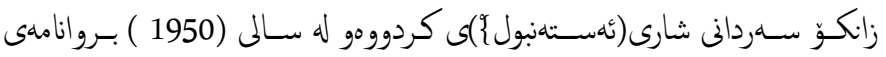

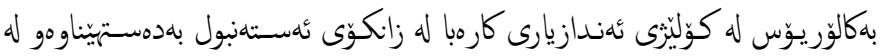

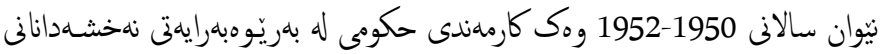

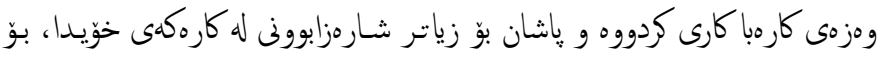

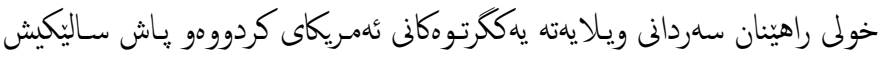

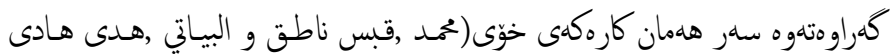

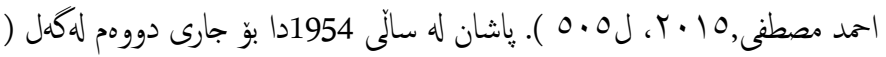

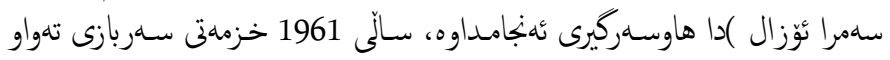

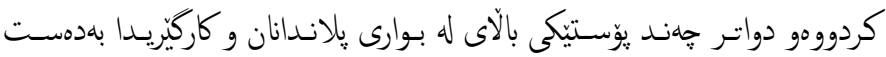

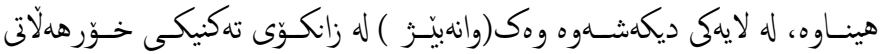

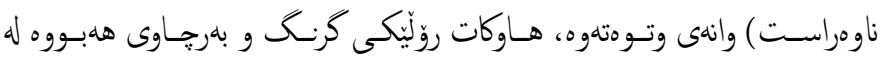

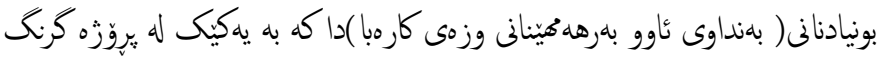

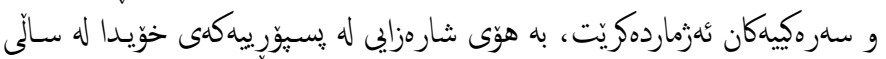

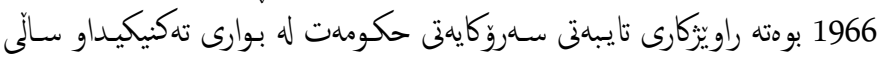

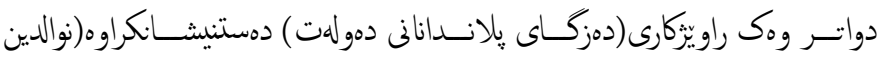

, محمد,1997، (51) .

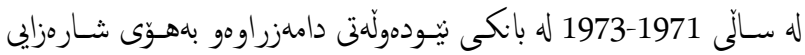

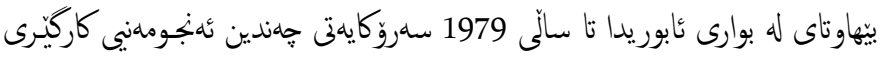

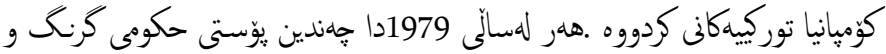

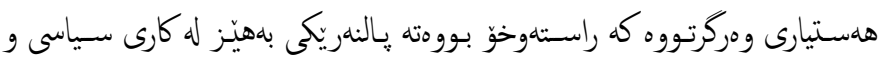

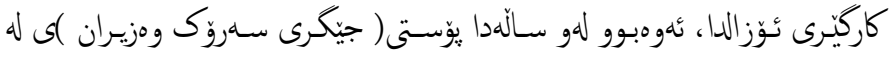

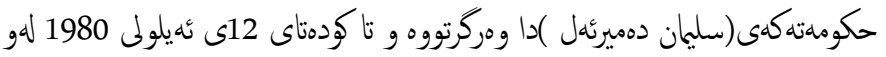

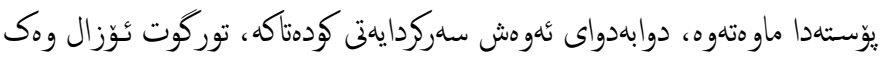

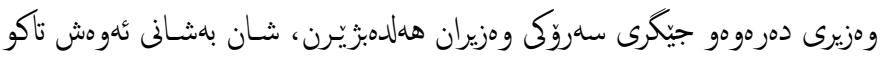

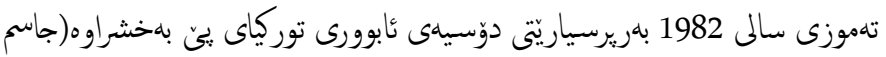

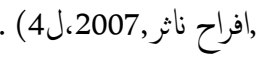

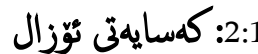

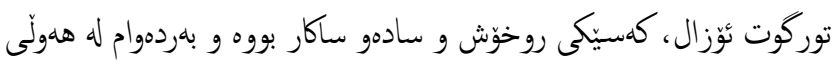

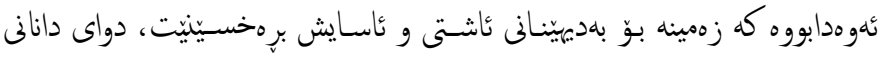

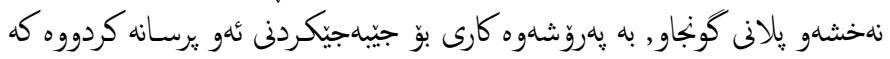

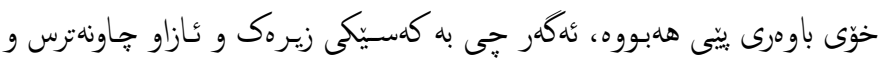

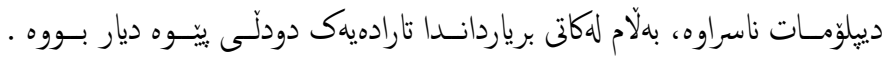

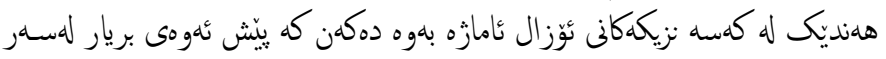

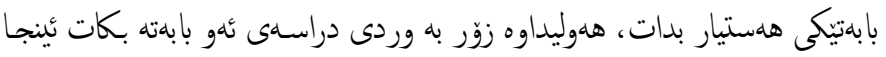

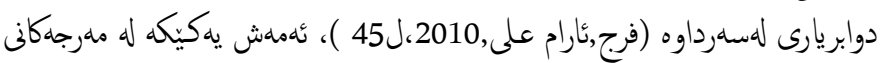

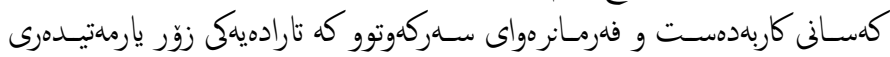

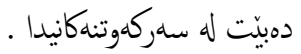

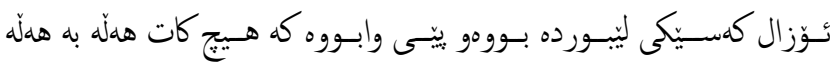

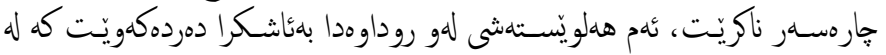

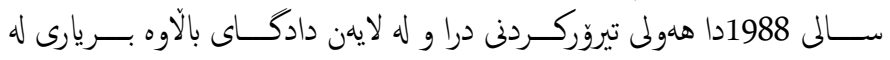

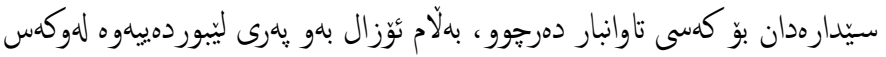




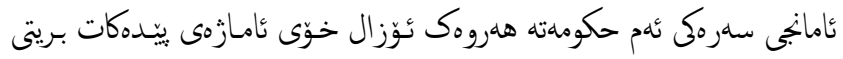

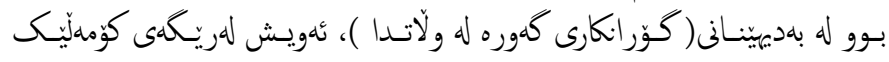

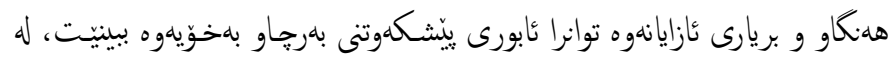

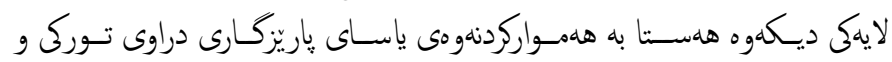

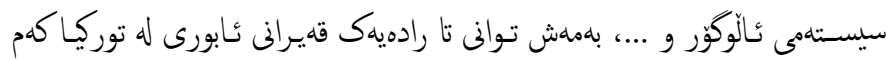

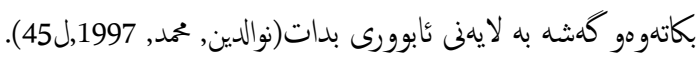

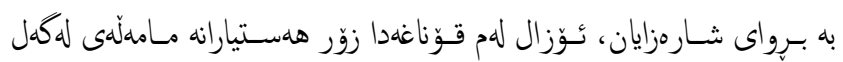

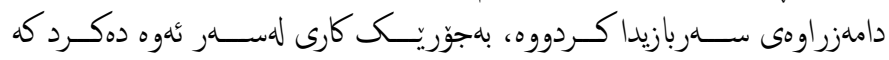

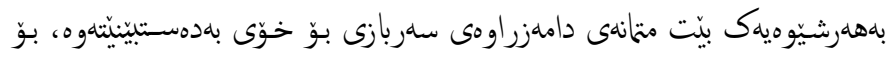

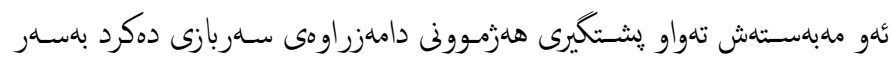

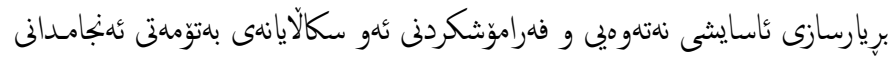

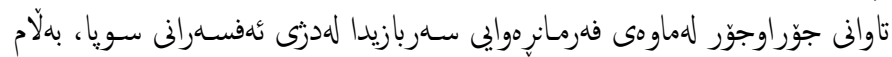

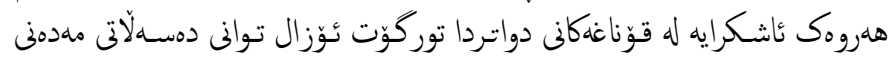

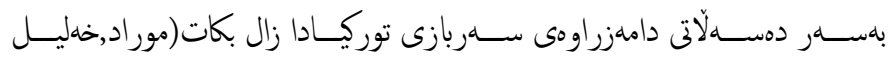

على, 2015، 204-303).

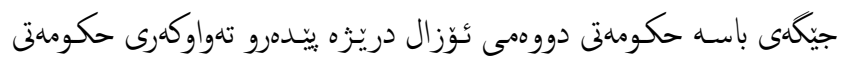

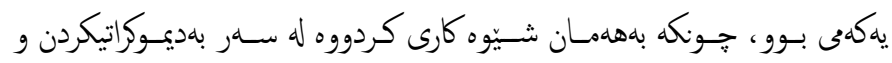

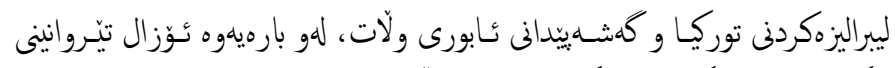

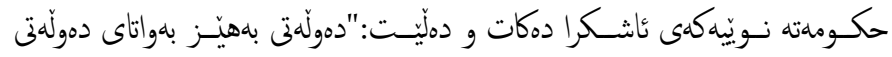

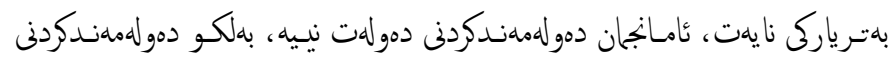

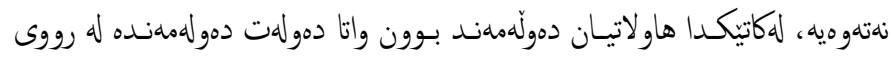

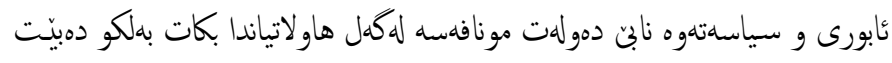

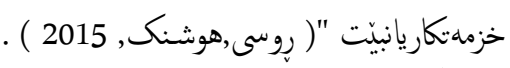

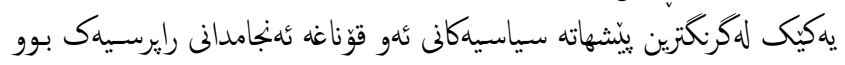

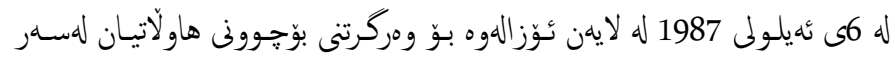

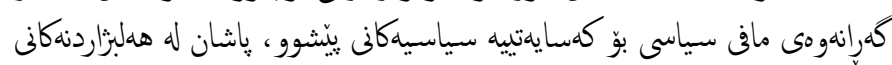

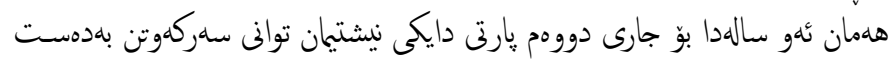

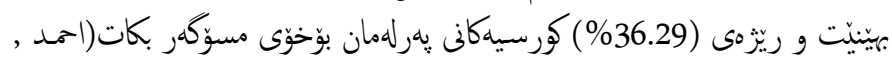

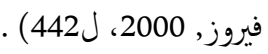

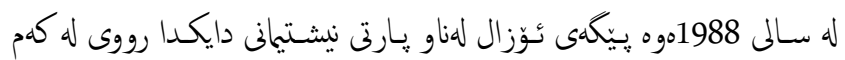

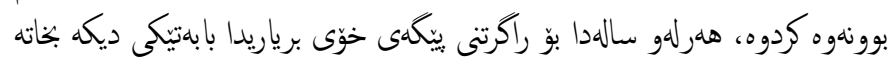

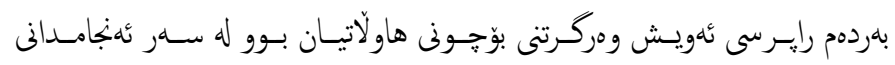

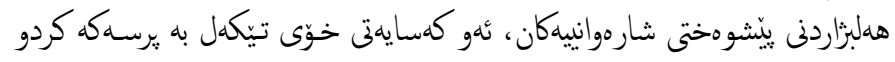

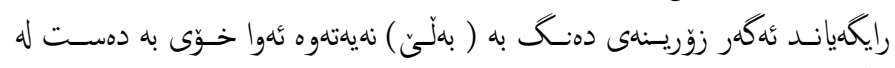

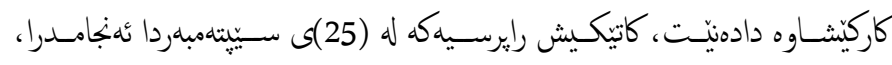

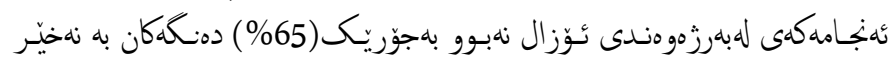

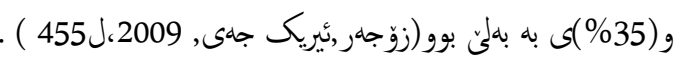

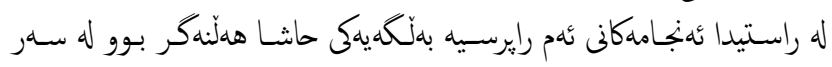

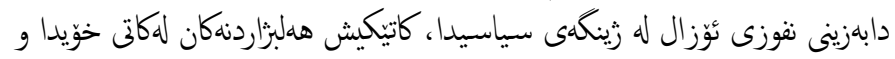

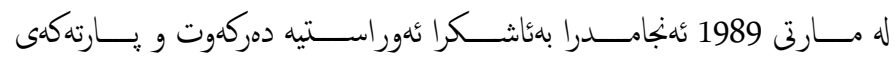

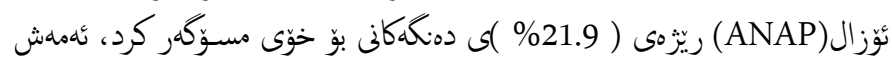

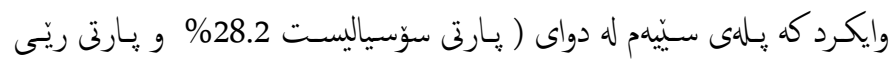

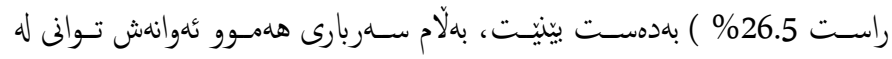

له 5ى كانونى يهكمى 1979دا يوّستى جيكرى سهروَكى دمزكاى بِلاندانانى

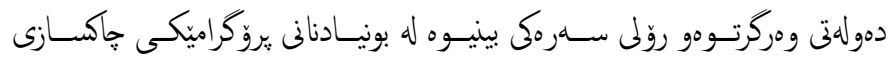

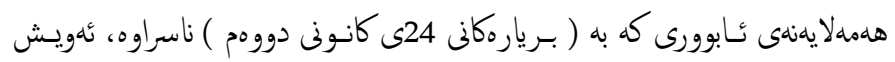

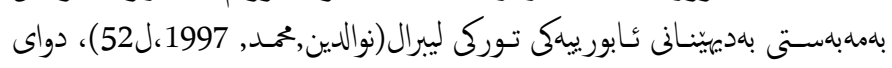

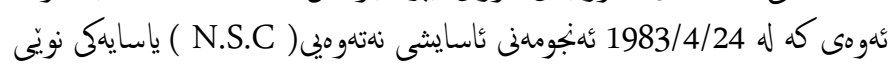

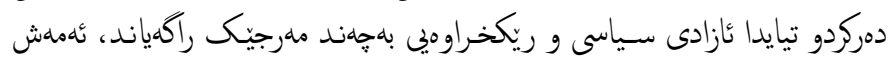

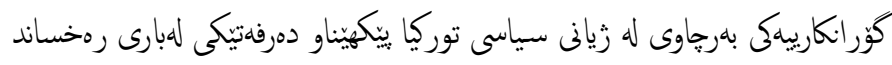

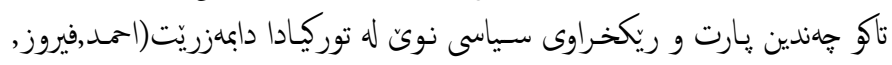

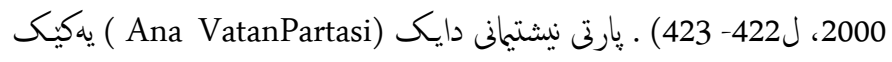

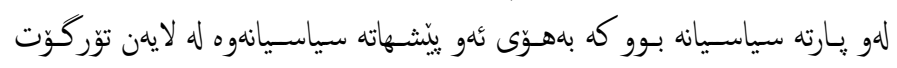

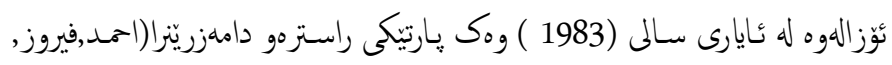

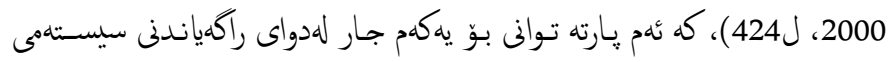

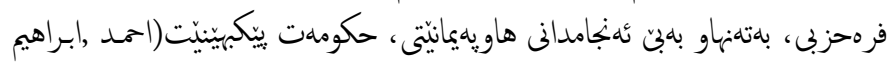

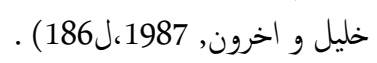

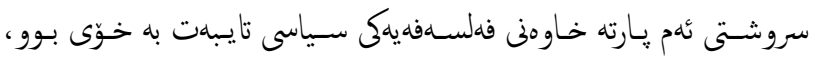

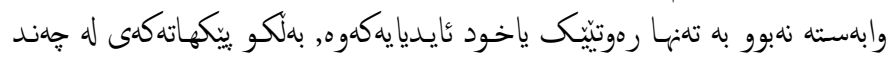

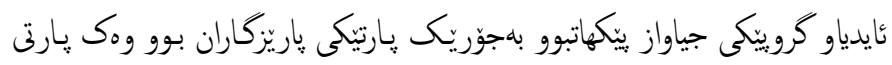

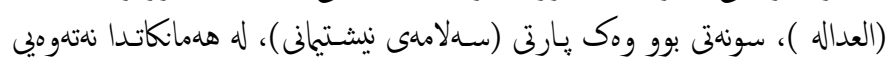

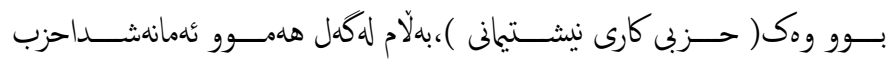

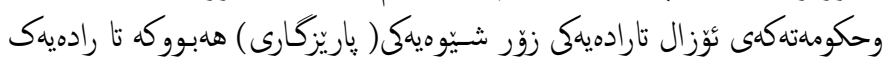

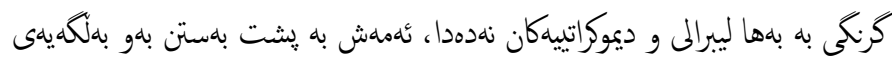

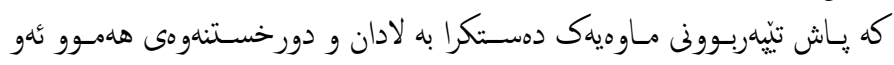

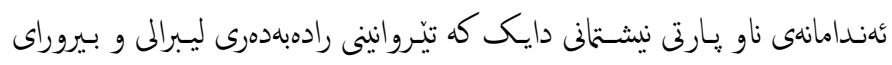

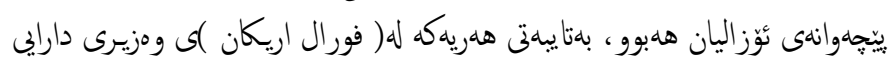

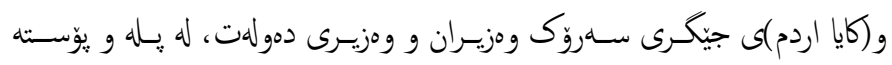

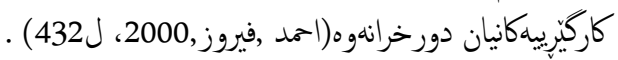

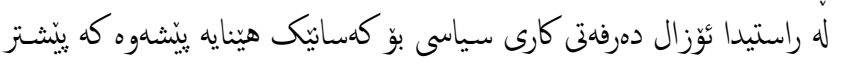

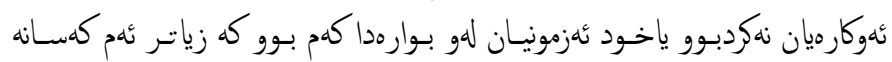

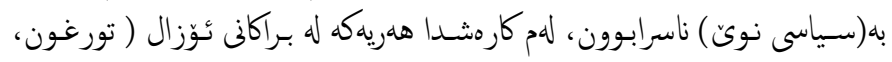

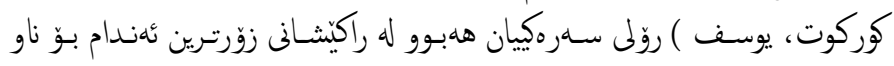

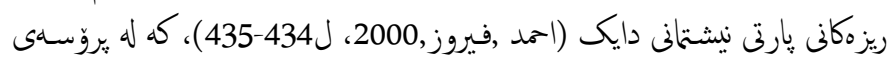

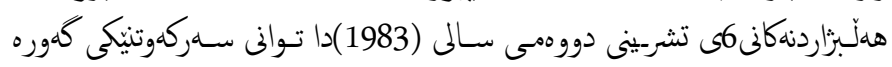

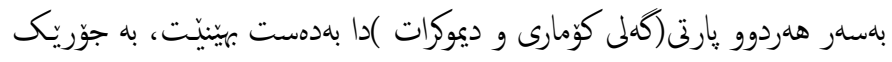

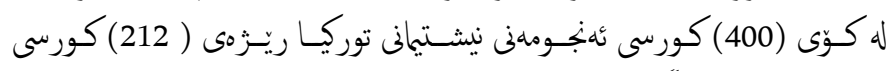

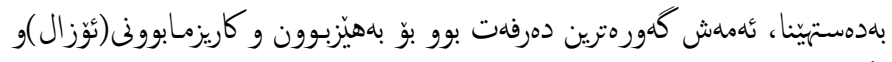

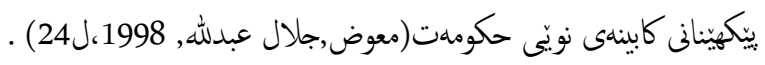

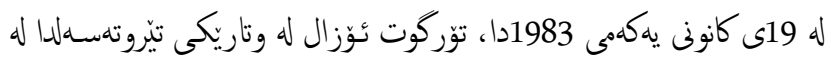

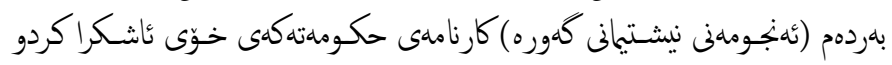

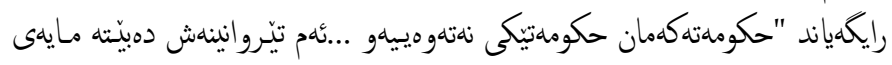

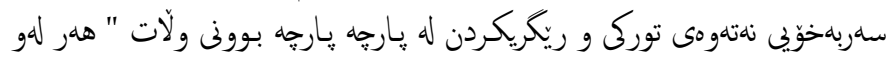

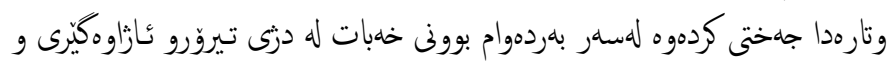

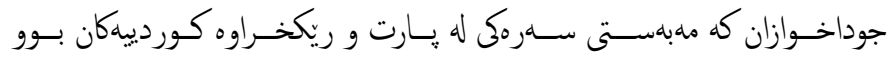

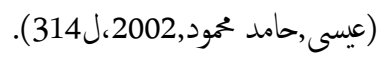




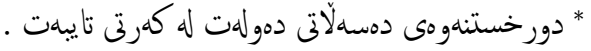

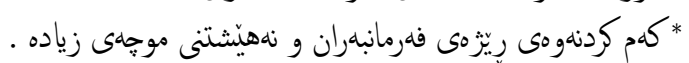

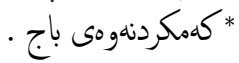

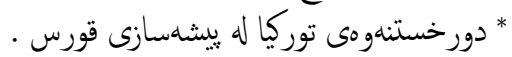

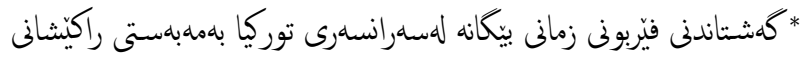

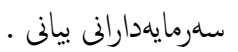

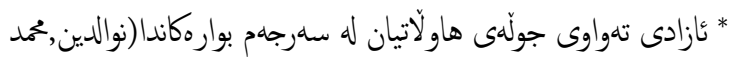

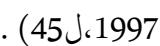

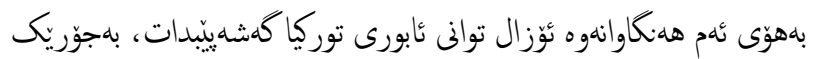

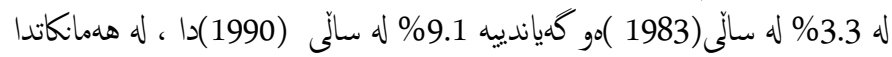

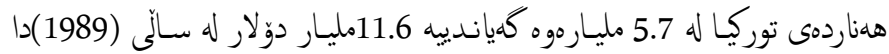

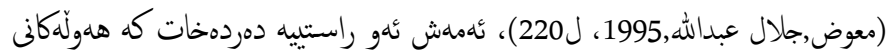

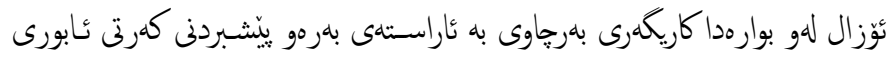

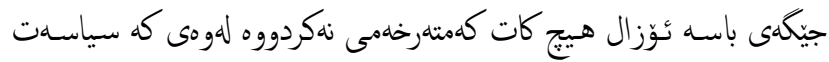

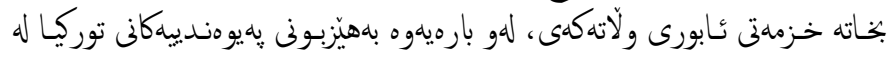

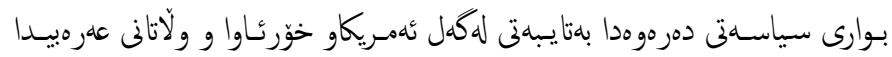

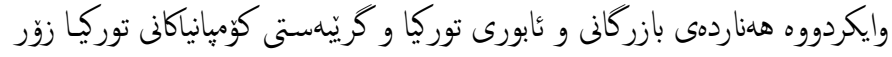

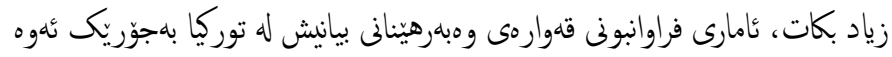

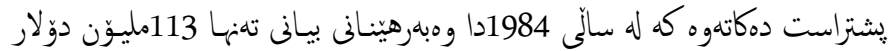

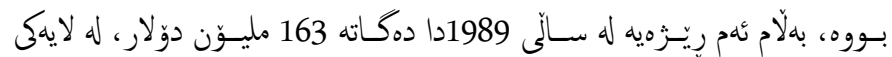

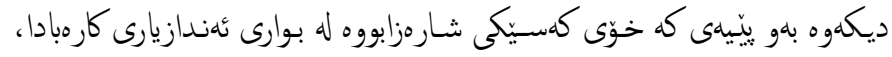

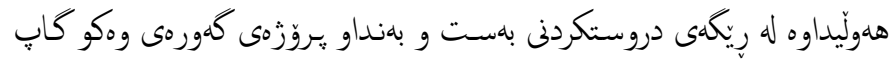
(GAP)

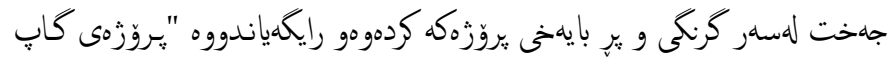

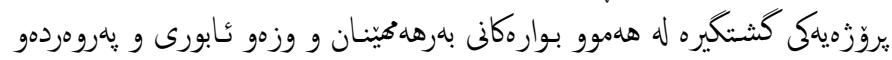

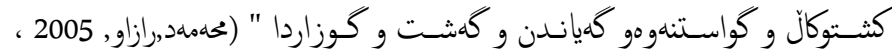

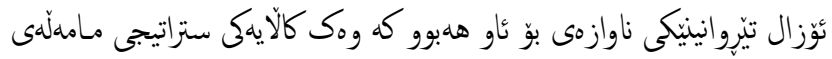

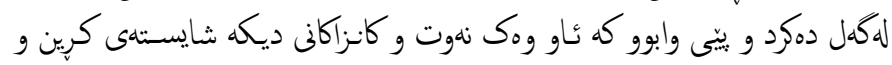

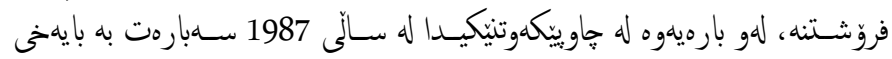

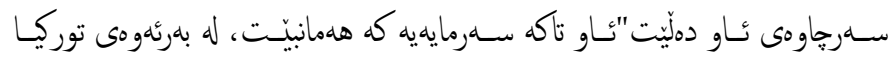

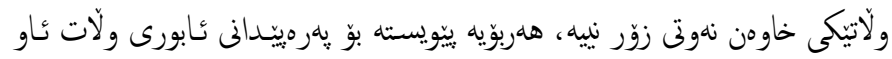

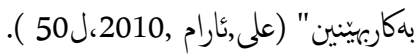

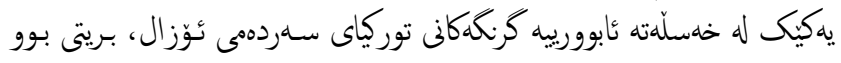

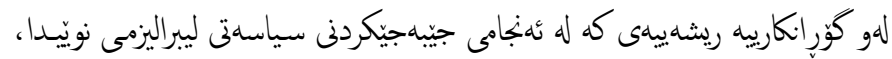

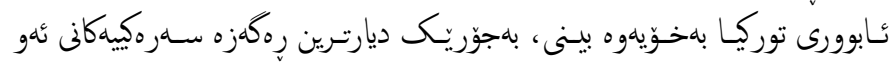

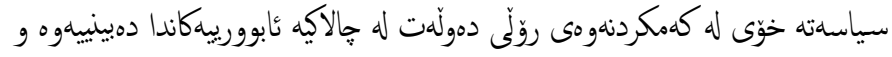

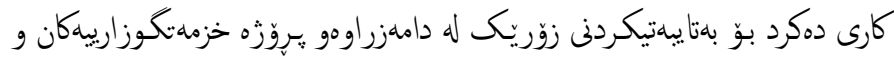

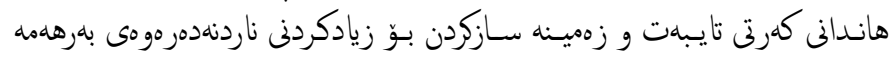

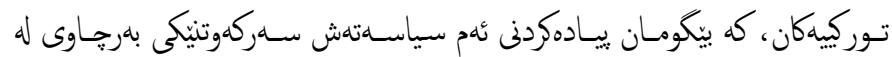

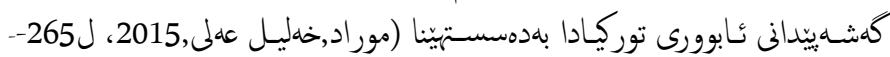

. (266

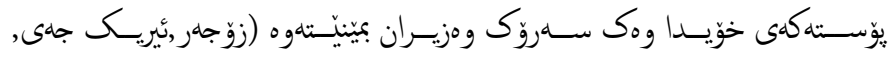
. (455」،2009

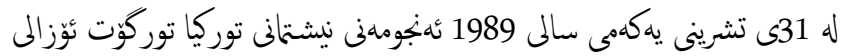

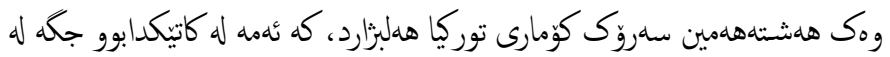

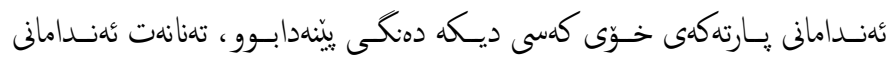

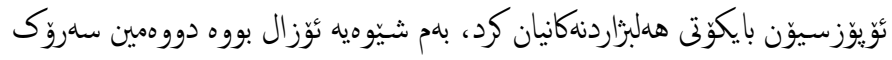

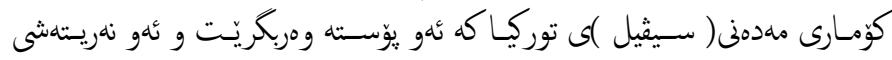

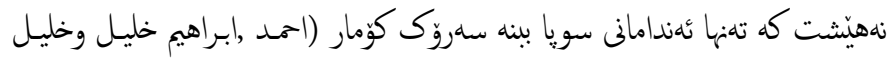

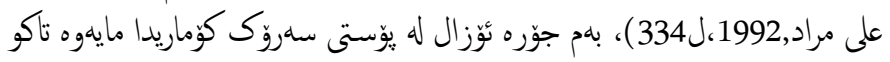

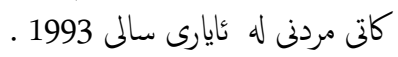

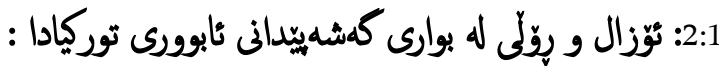

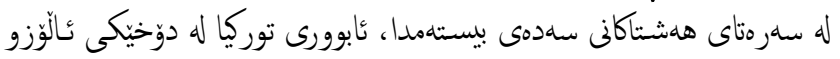

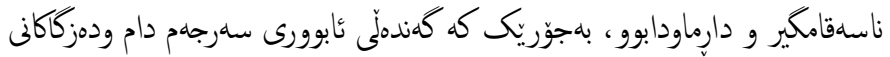

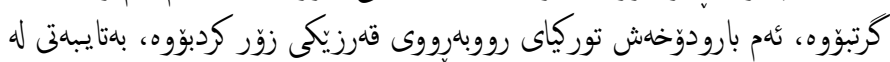

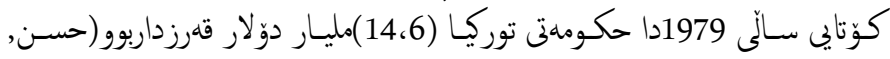

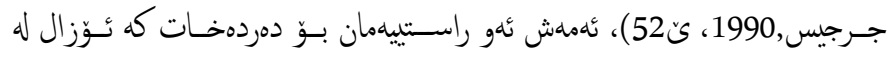

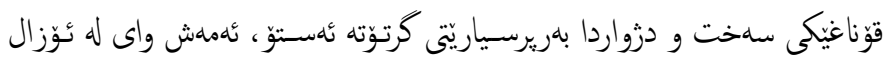

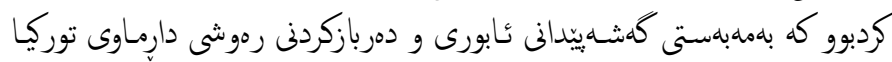

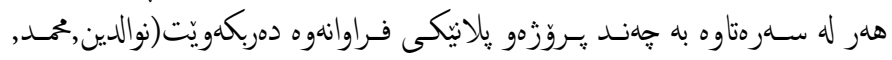

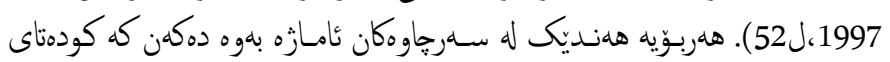

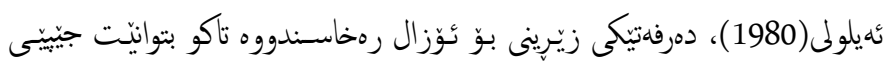

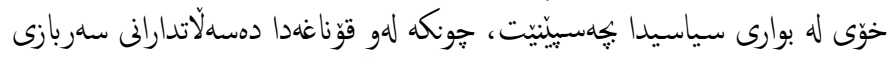

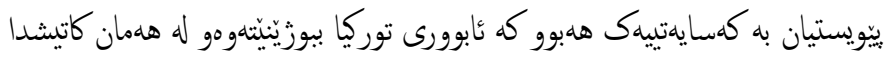

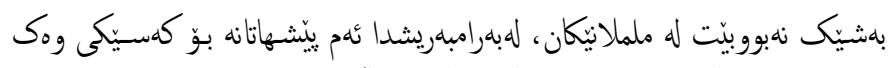

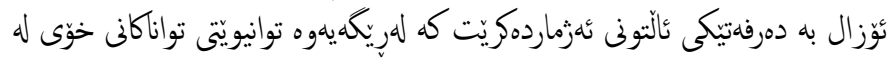

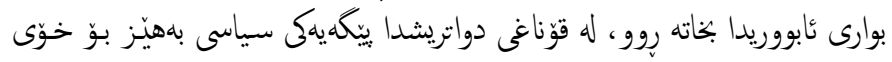

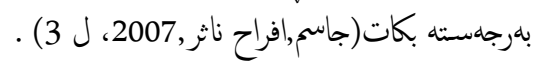

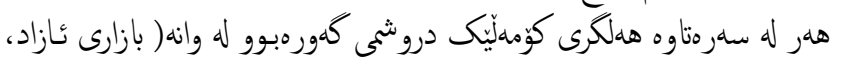

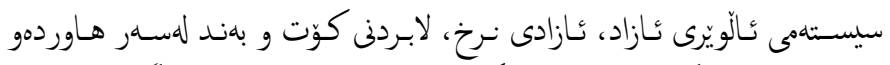

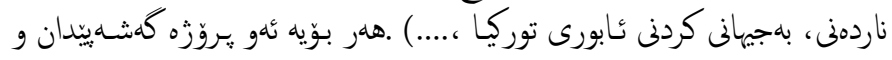

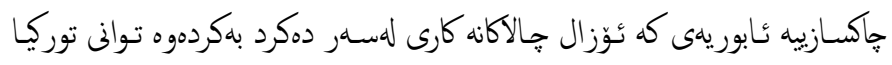

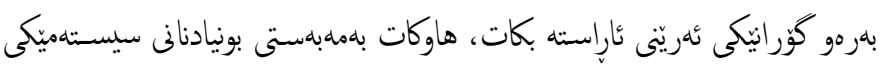

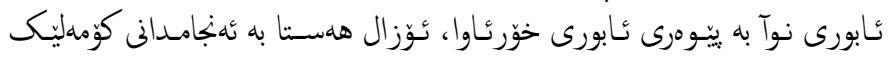

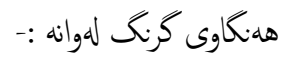

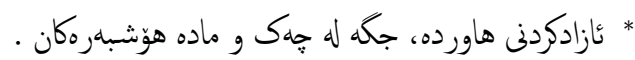

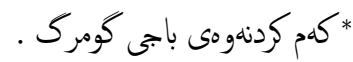

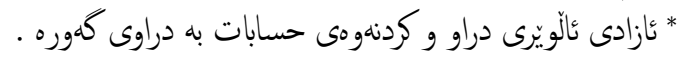

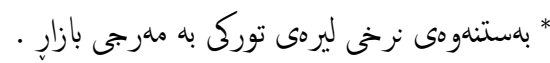

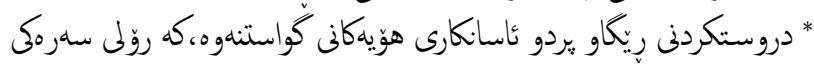

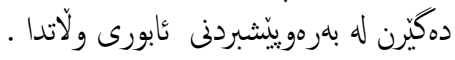
*نهيُشتنى كمرتى كشتى له توركيا . 


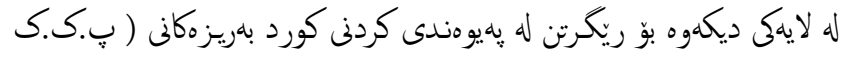

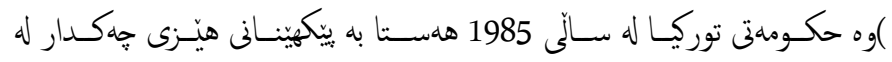

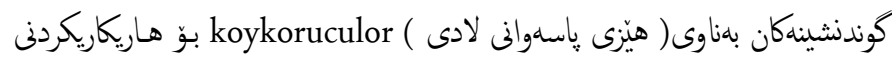

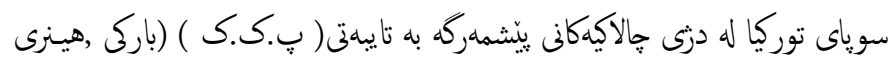

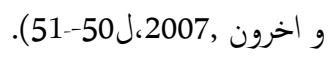

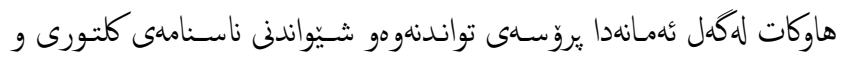

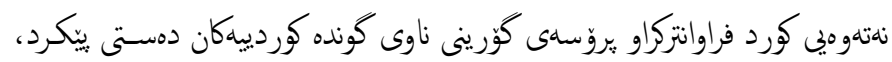

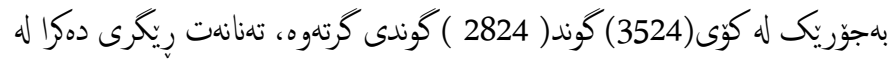

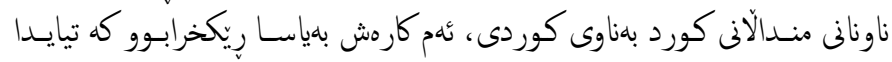

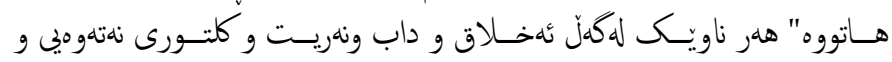

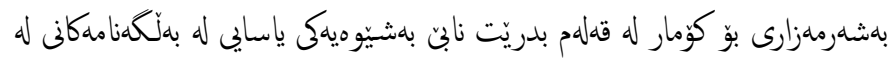

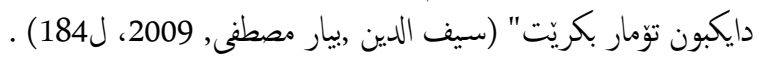

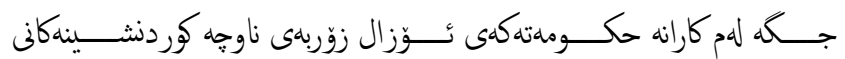

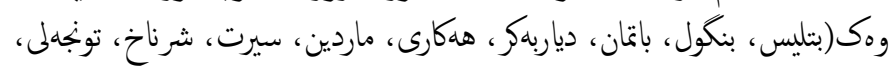

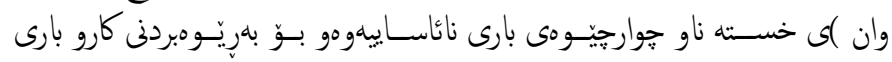

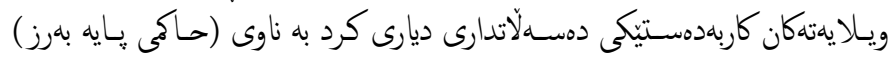

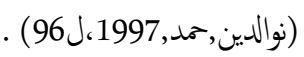

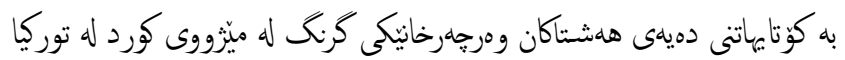

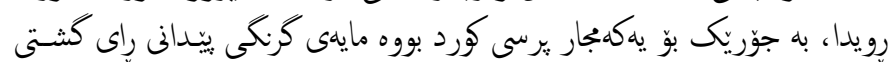

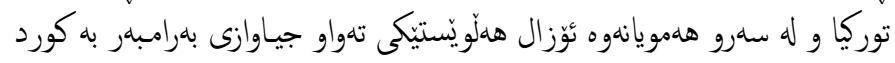

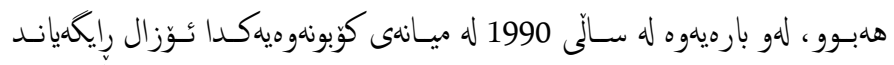

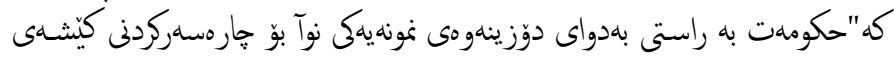

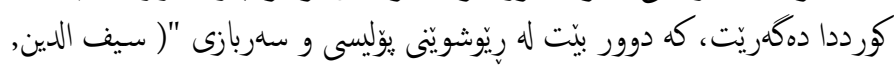

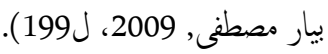

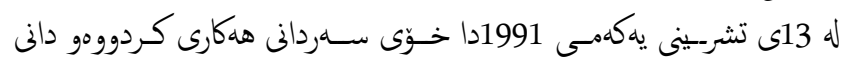

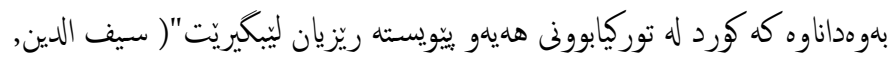

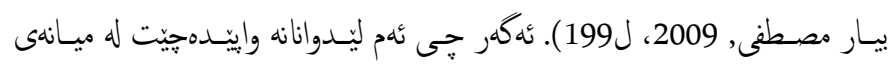

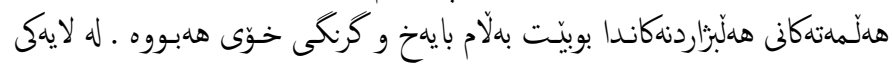

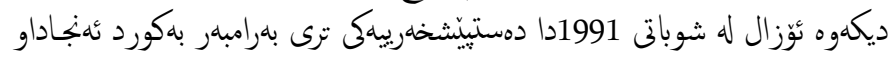

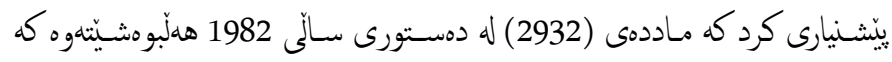

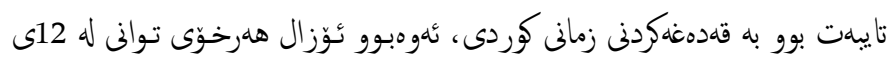

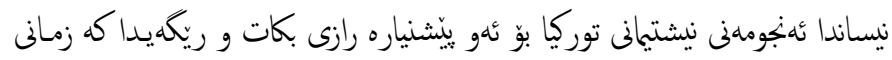

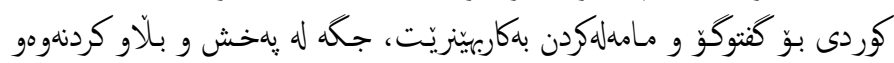

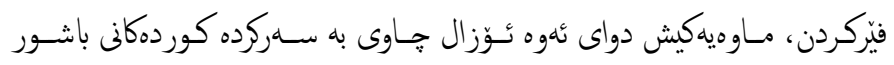

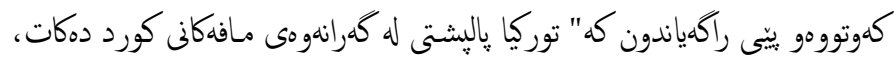

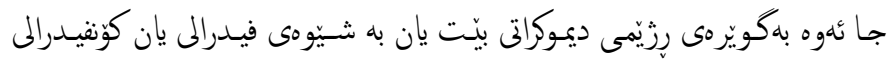

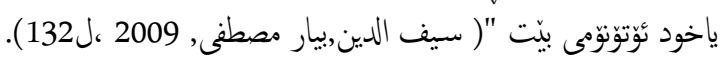

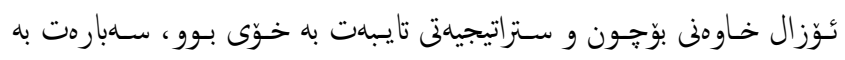

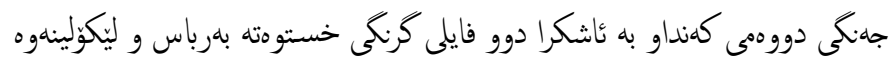

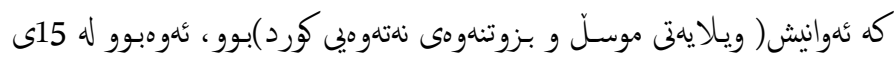

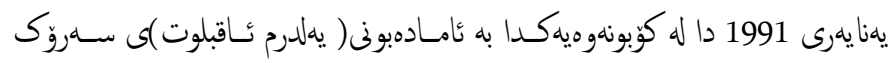

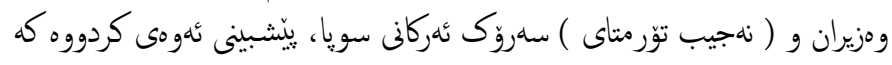

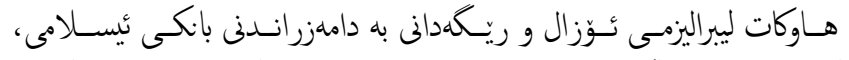

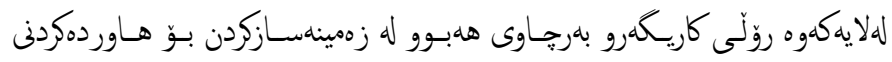

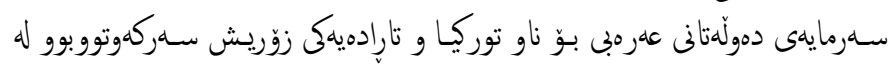

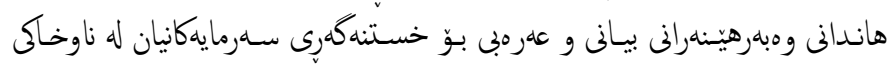

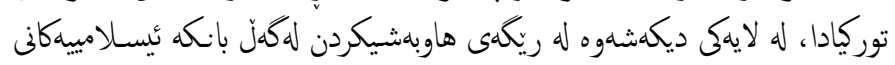

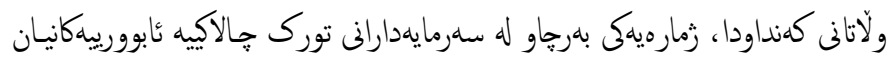

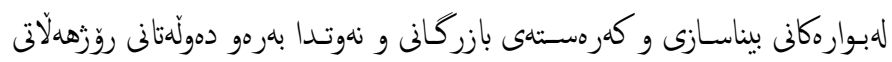
ناوهراست كواستهوه(موراد,خهليل عهلى,2015، ل271--272).

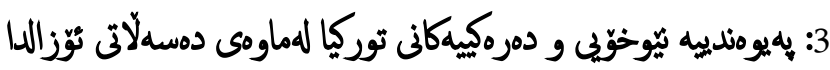 1:3: توركوت ثوزال و يرسى كورد :}

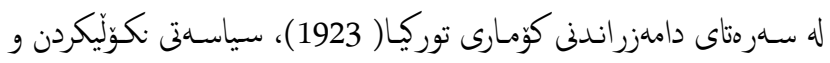

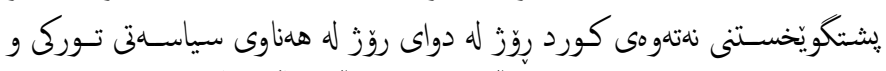

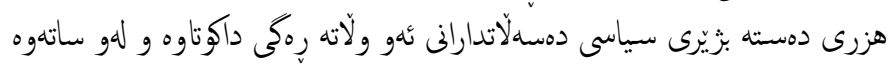

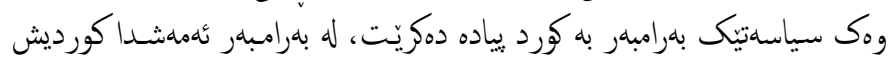

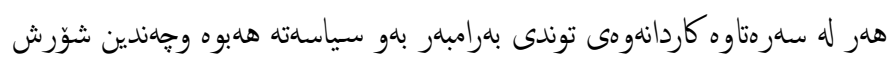

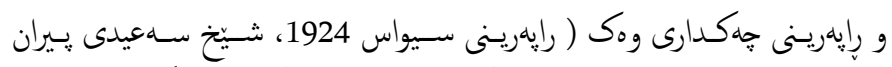

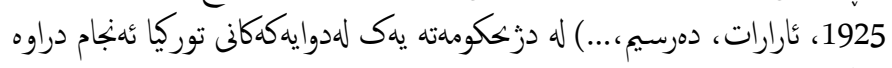

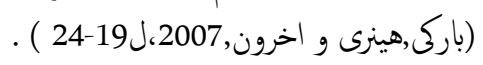

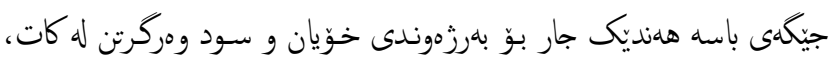

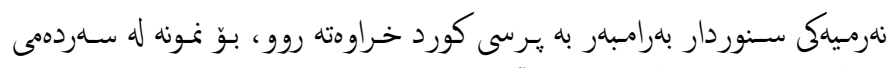

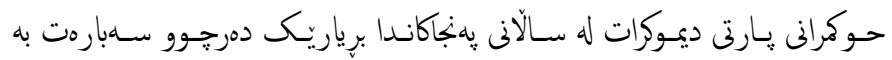

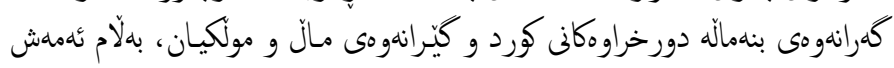

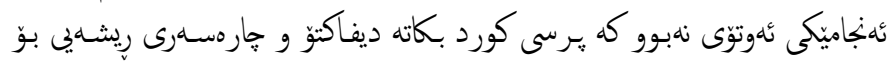

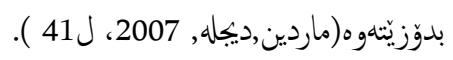

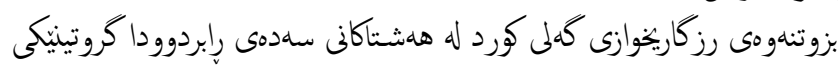

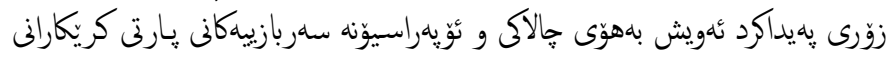

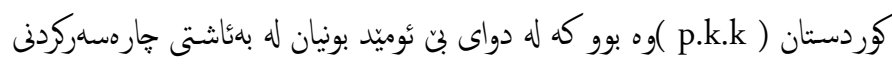

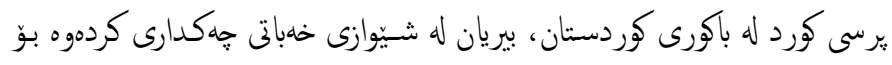

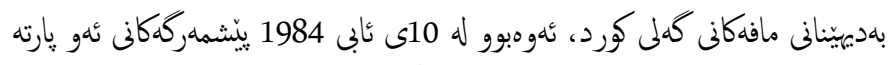

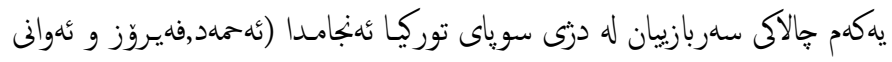

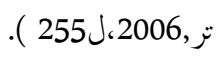

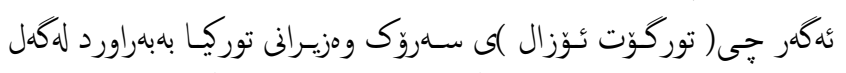

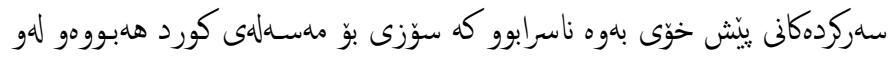

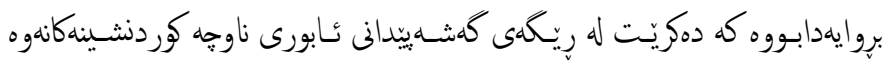

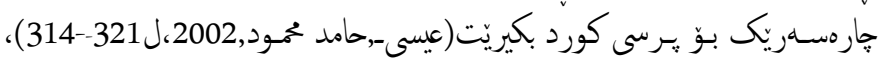

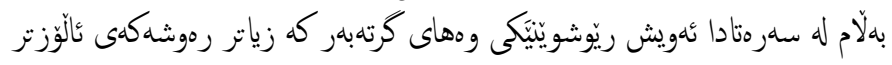

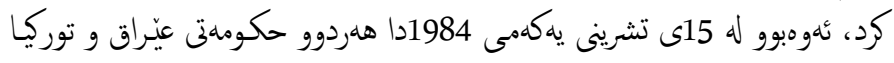

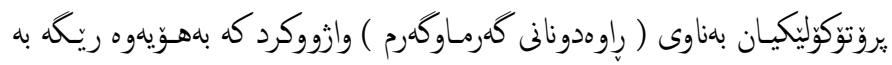

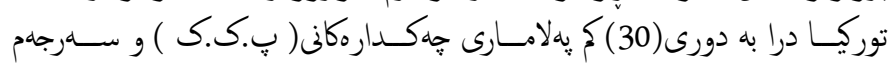

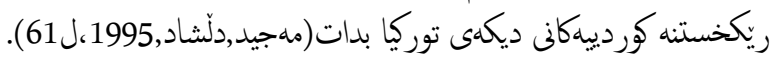




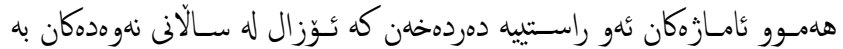

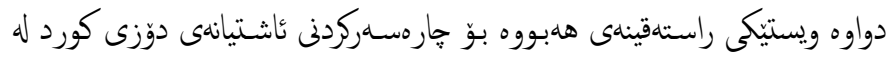

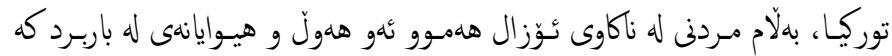
سالآنيكى بوو كورد خهاباتى دهرد له يبيناوياندا.

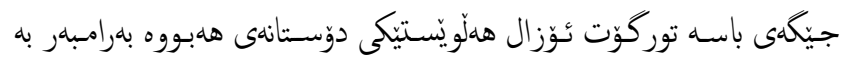

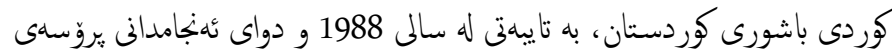

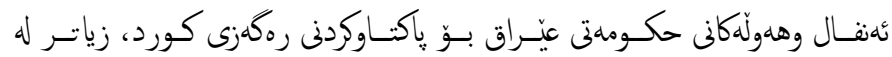

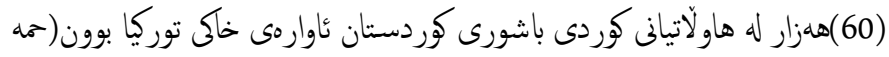

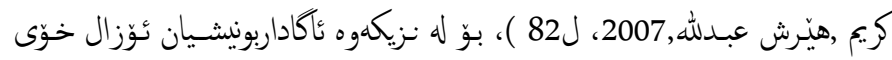

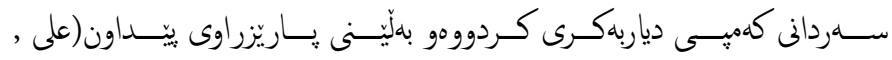

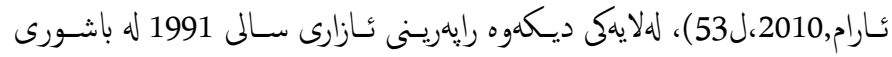

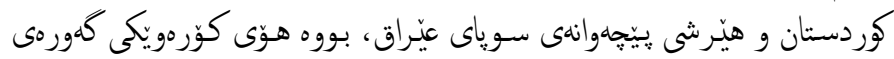

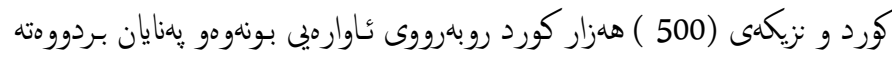

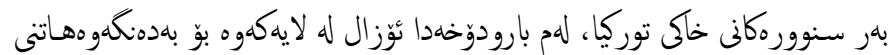

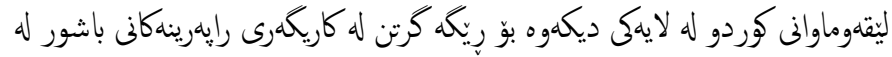

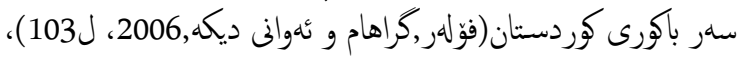

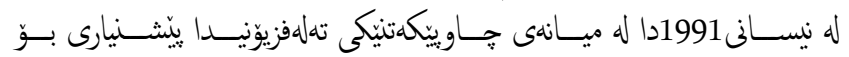

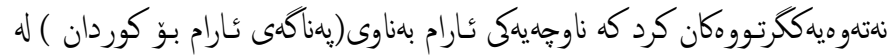

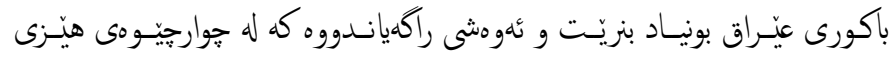

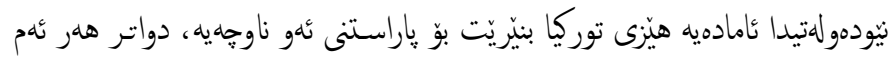

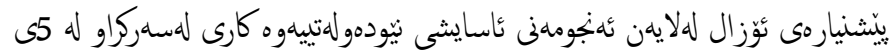

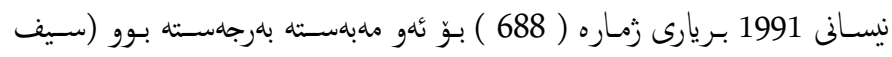

الدين,بيار مصطنى, 2009 ، 2061 (196).

\section{2:3: بهيوهندييه دهرهكيهكانى توركيا له سهردمى حوكرإنى ثوززالدا 1:2:3 : توريكا و ثنمريكا :}

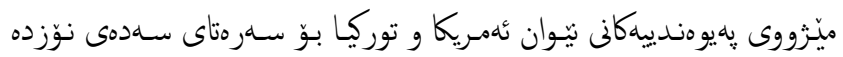

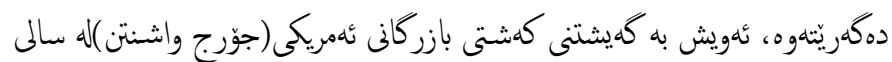

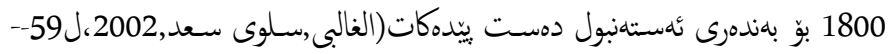

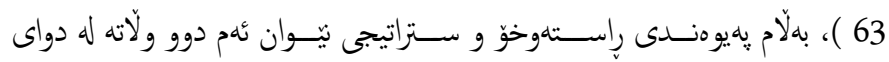

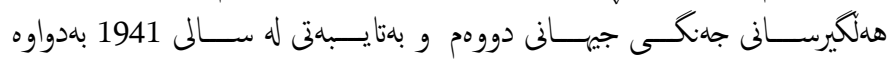

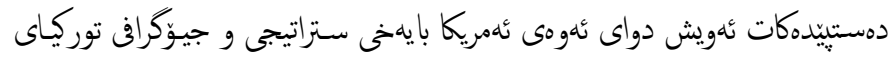

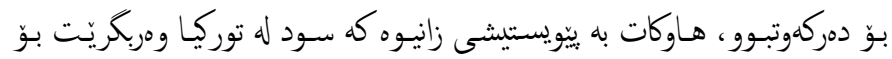

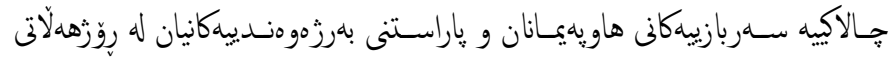

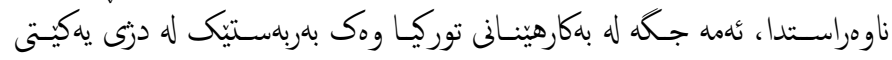

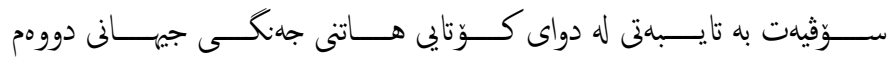

(حسن,جرجيس 1990 ، ل32 ).

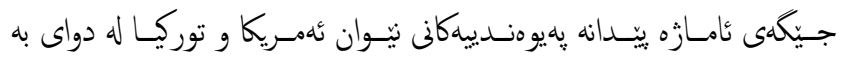

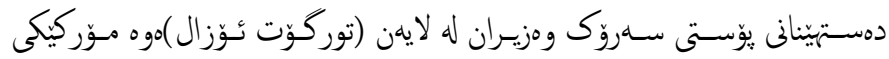

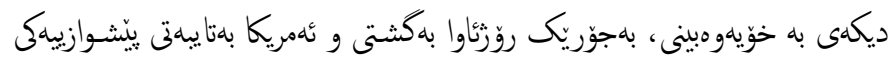

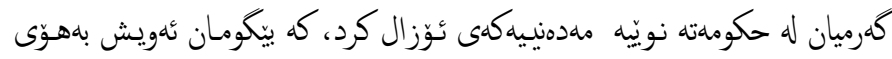

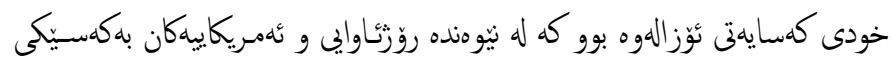

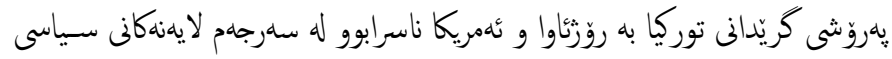

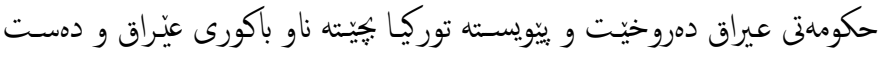

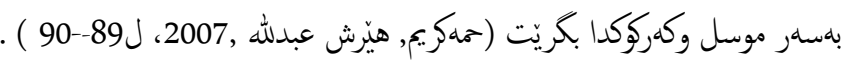

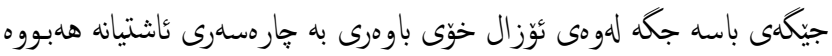

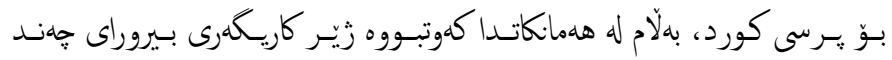

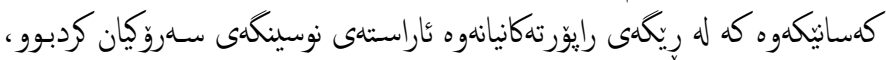

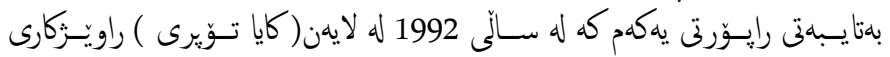

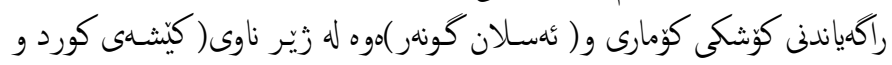

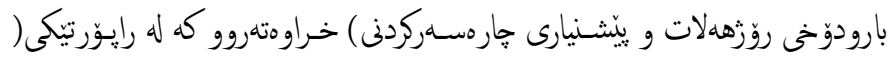

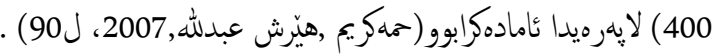

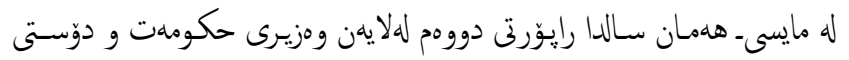

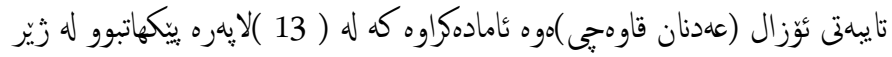

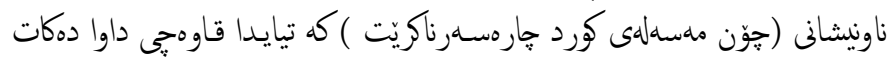

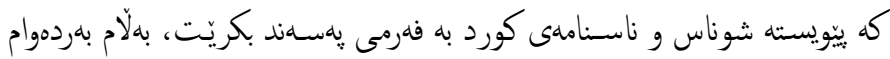

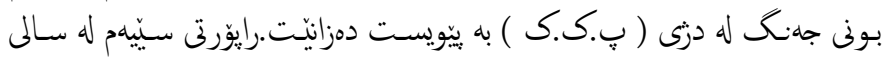

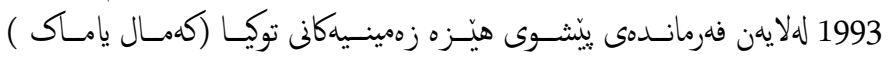

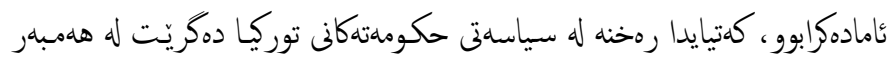

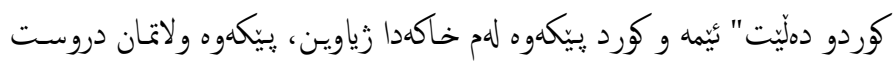

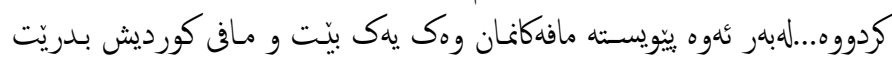

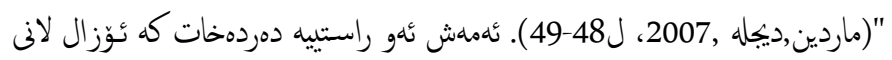

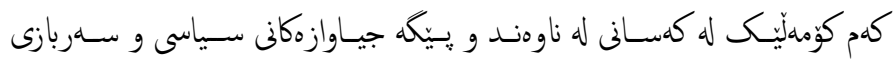

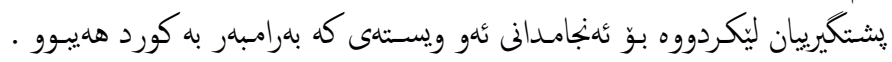

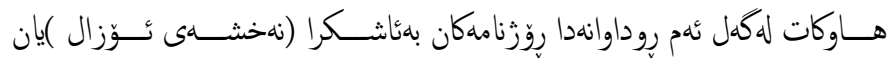

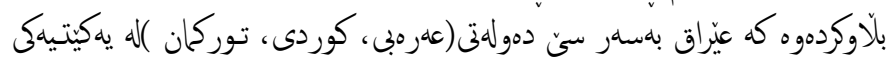

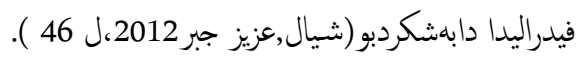

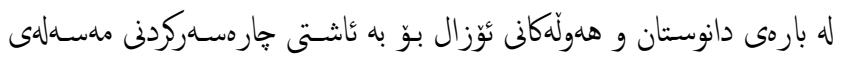

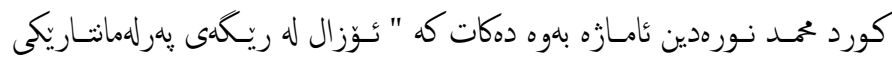

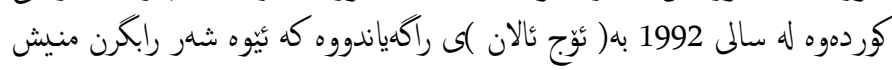

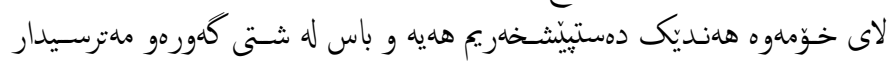

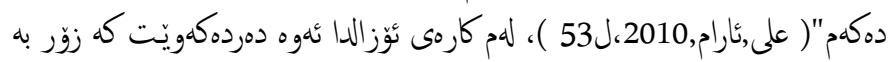

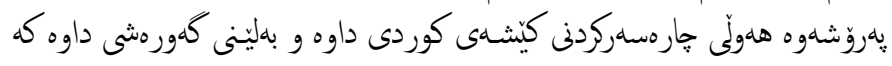

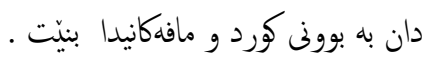

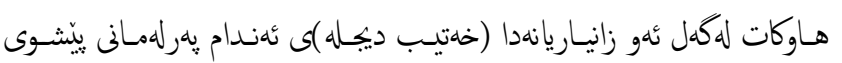

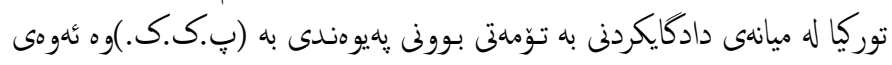

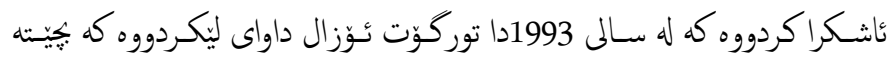

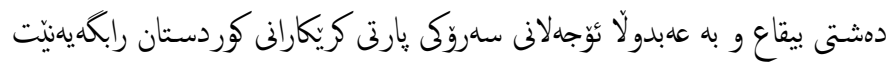

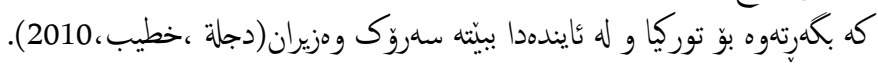

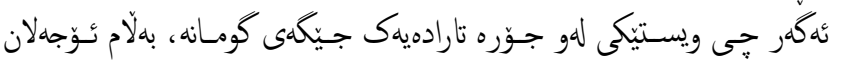

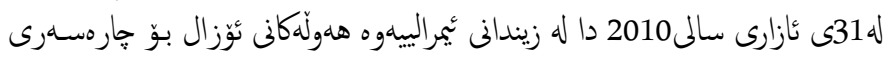

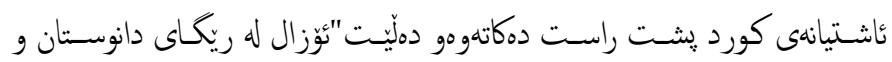

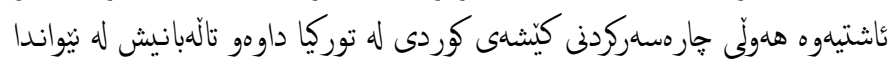

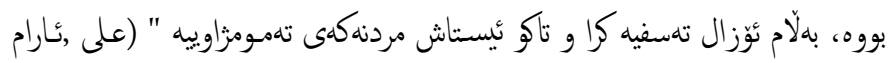

. (53)،2010, 


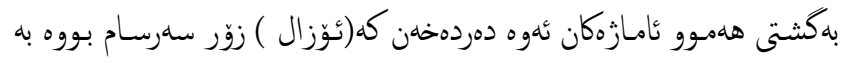

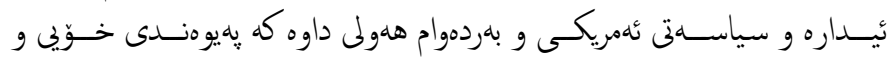

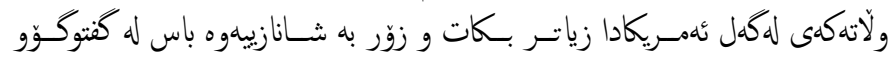

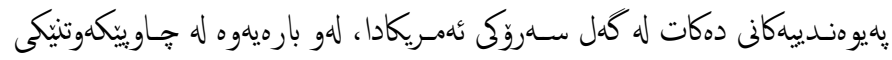

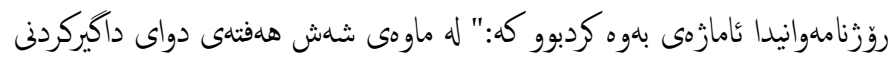

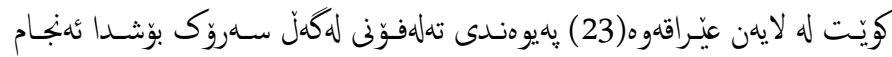

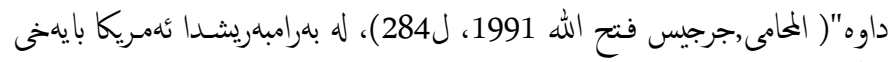

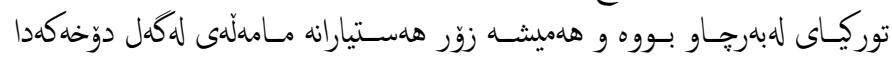

كردووه.

2:2:3 هليوهندييه هلريّمييهكانى توركيا :

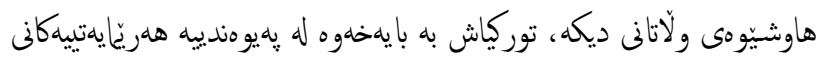

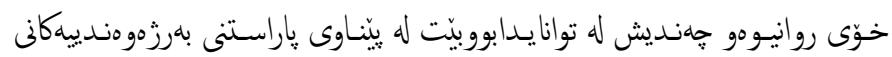

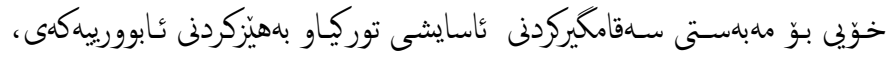

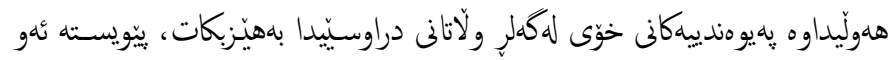

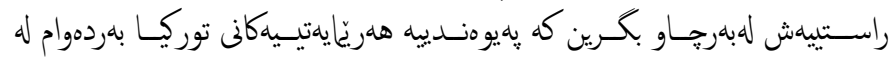

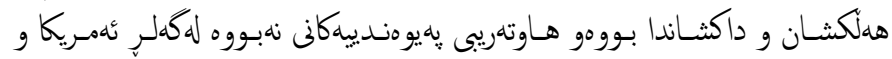

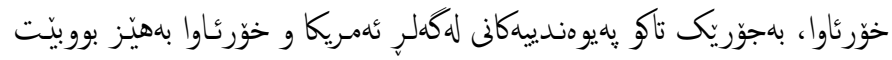

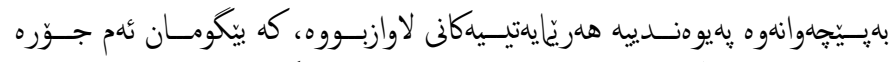

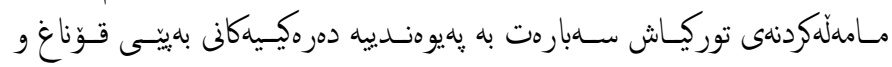

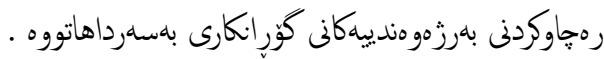

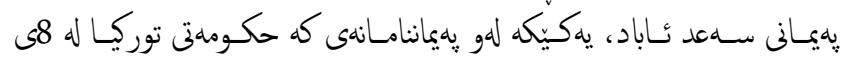

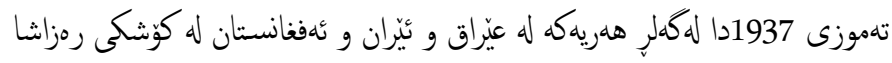

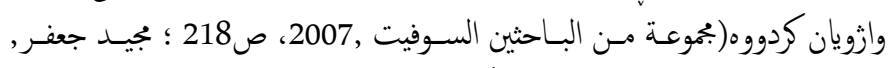

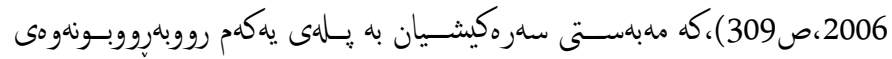

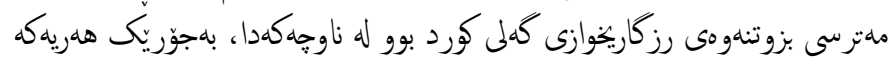

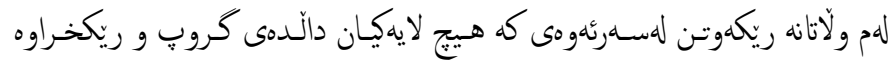

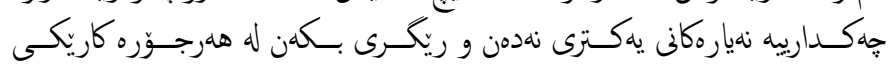

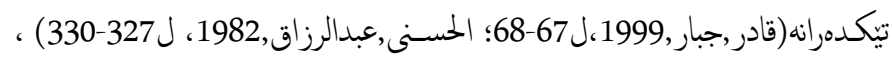

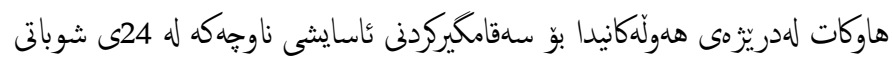

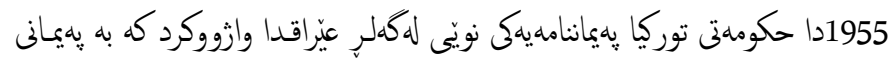

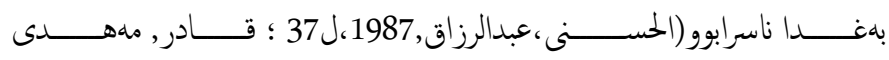

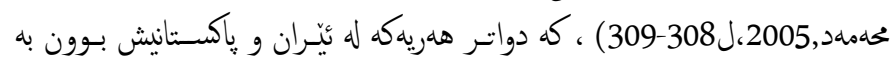

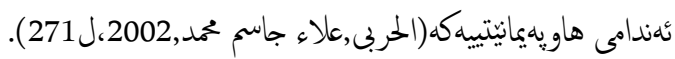

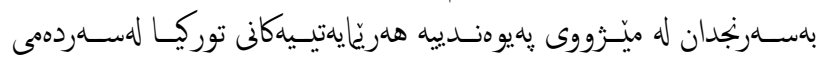

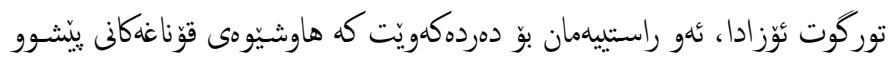

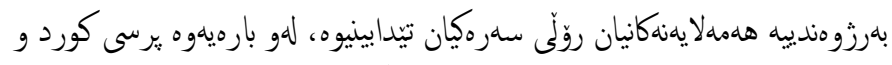

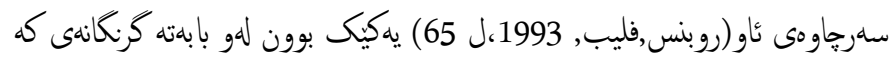

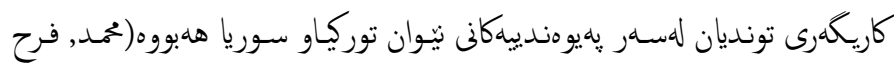

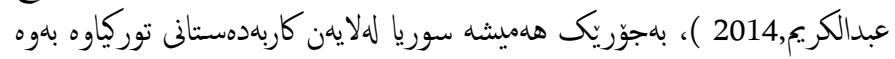

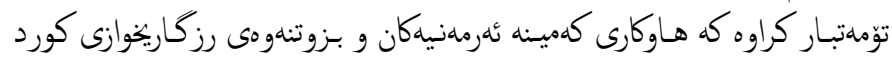

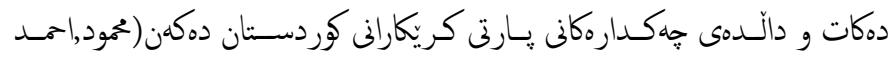

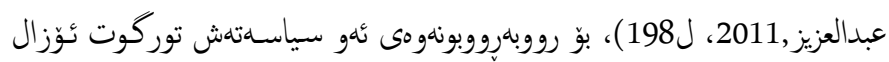

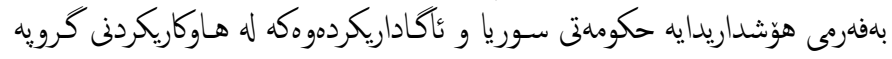

و سهربازى و ئابوورى و بازركانى وكلتورى. له لايهك ديكهوه زانيـاريبهكان ثنهوه

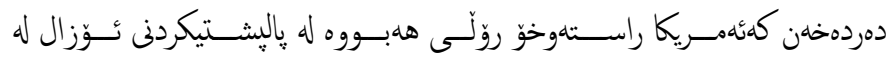

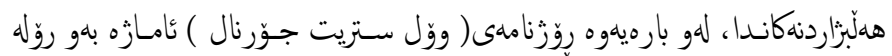

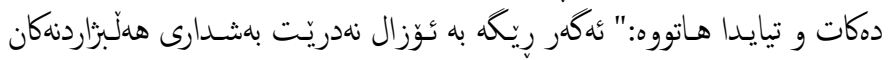

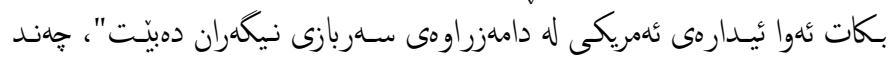

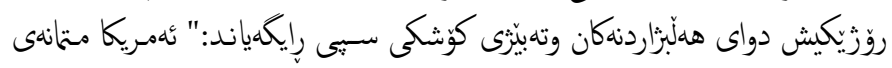

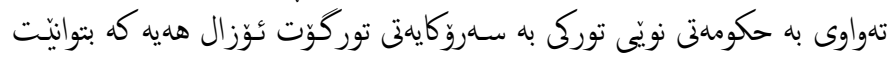

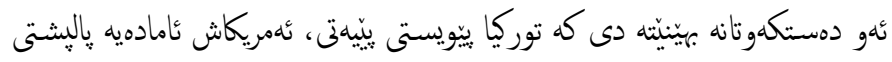

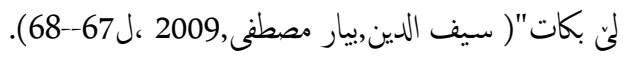

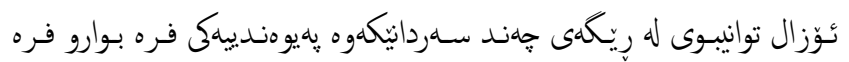

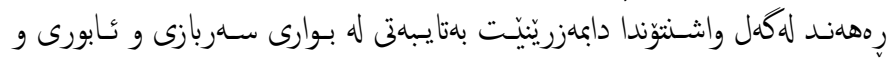

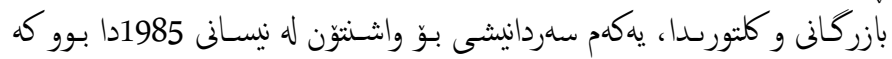

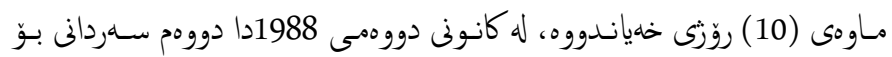

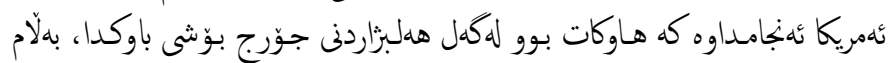

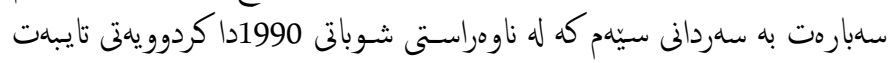

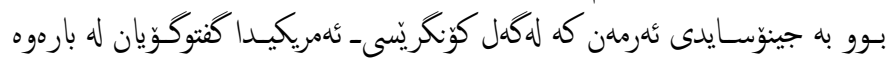

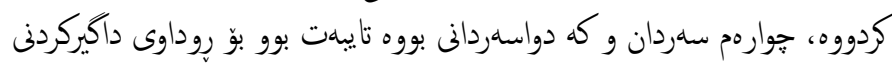

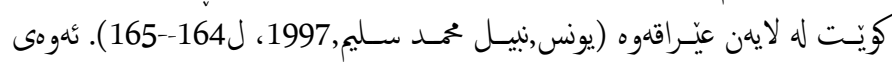

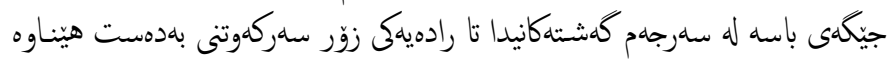

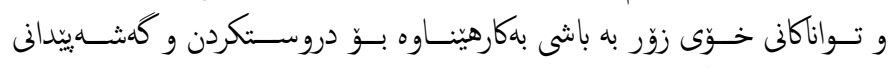

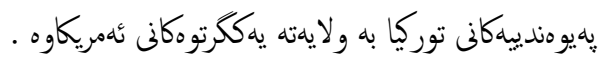

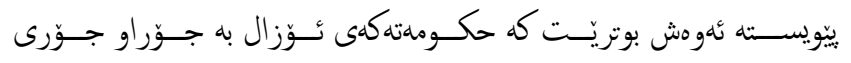

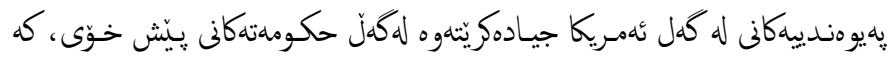

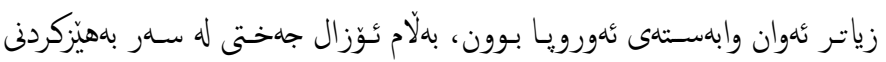

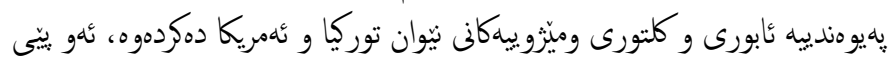

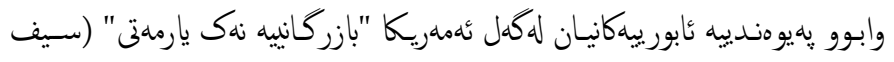

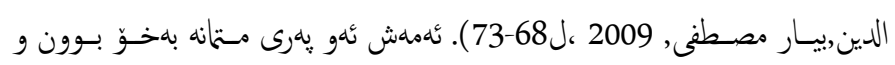

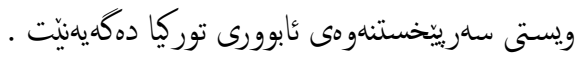

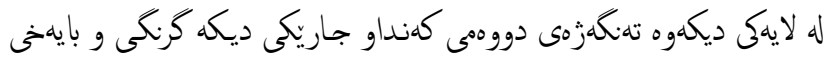

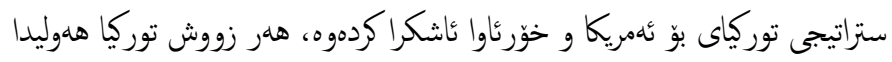

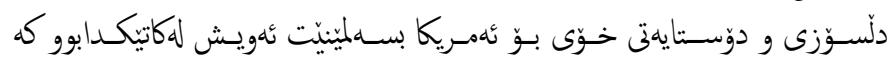

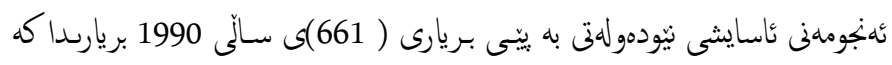

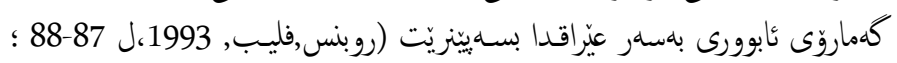

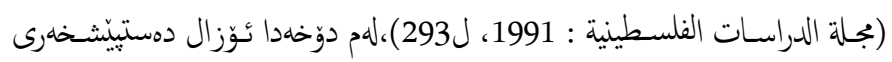

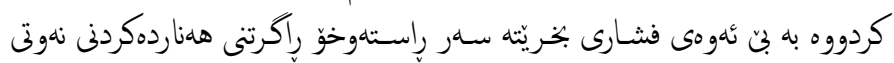

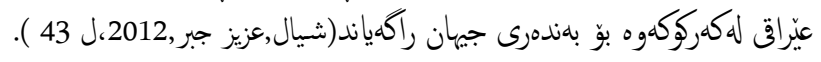

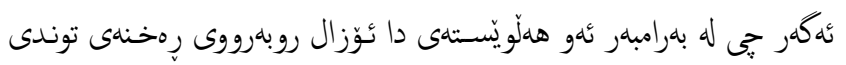

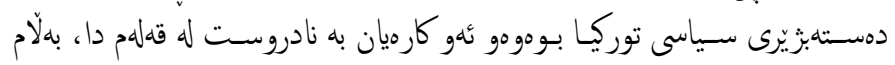

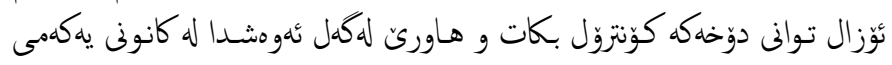

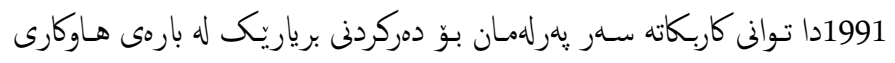

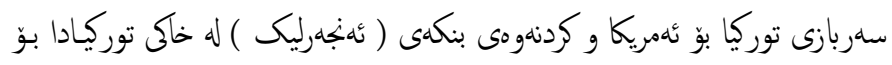

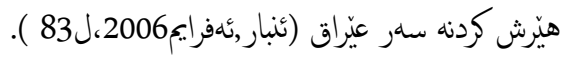




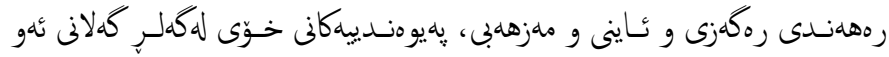

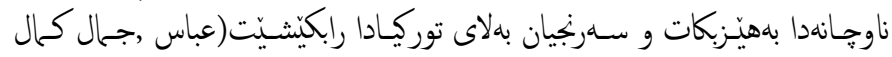

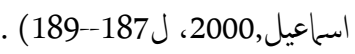

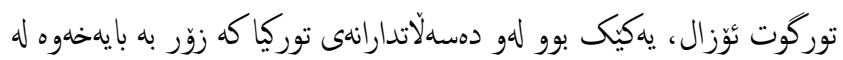

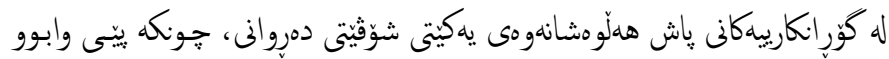

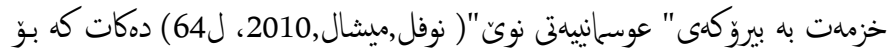

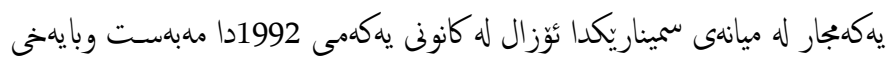

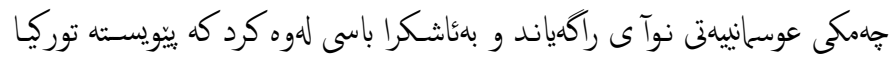

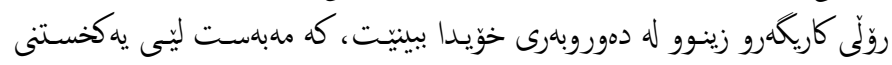

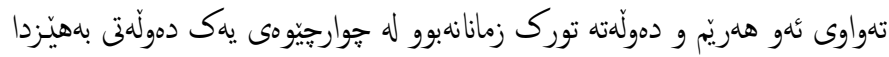

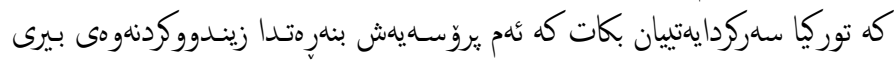

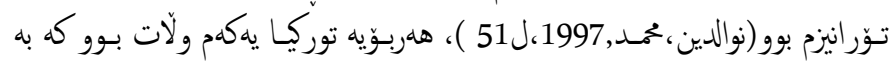

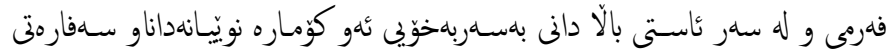

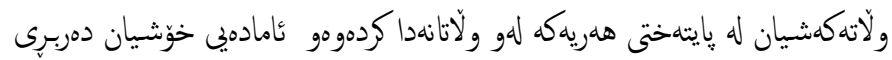

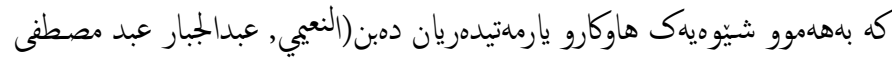

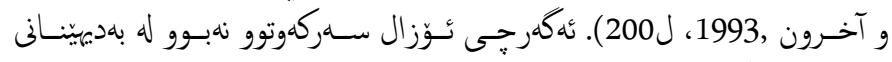

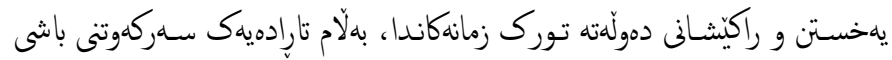

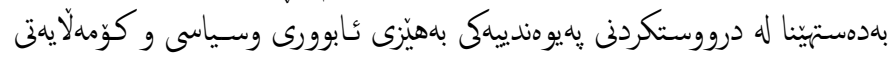

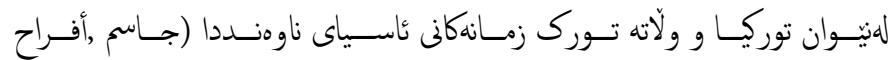

\section{تونجام}

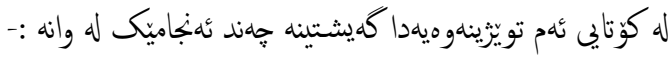

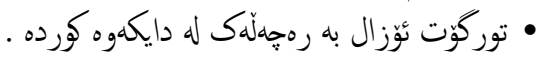

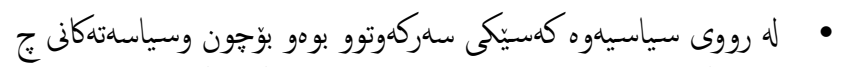

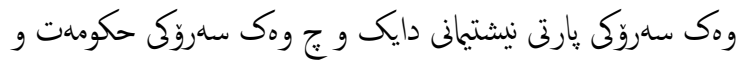

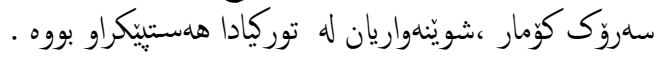

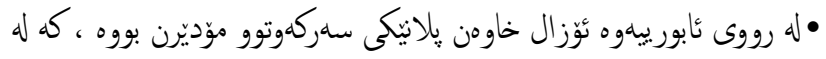

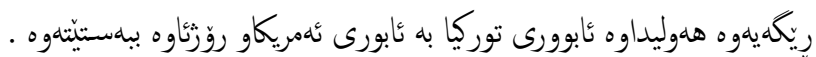

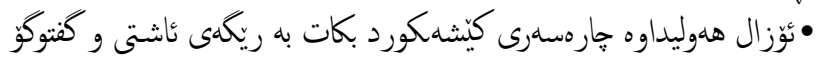

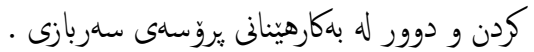

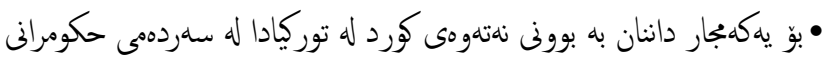

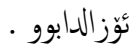

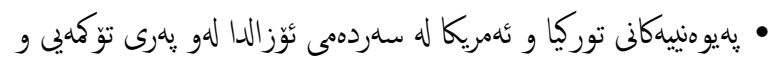

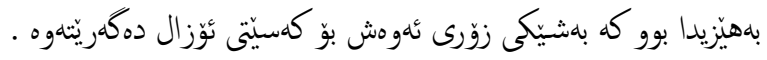

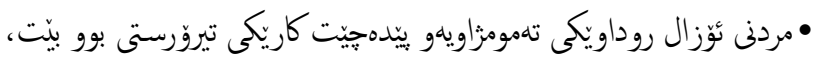

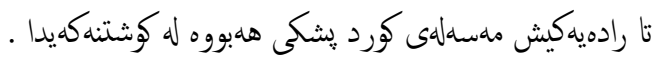

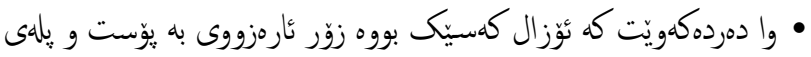

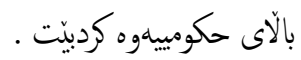

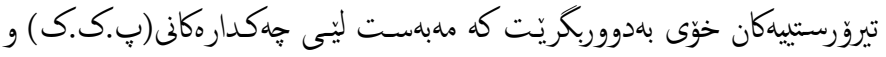

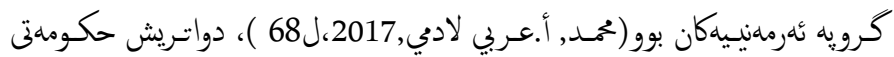

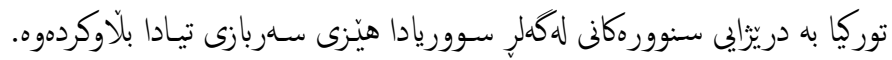

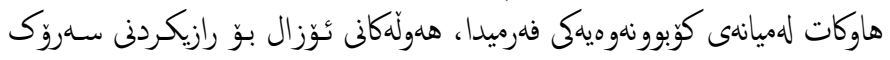

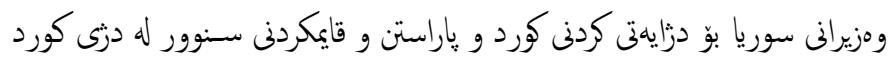

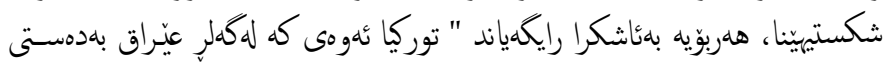

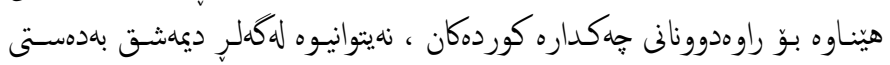

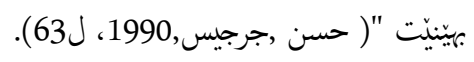

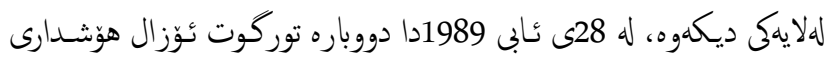

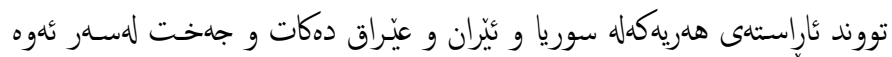

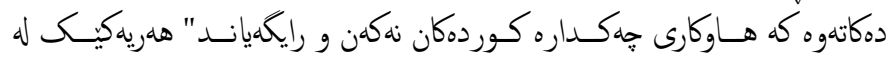

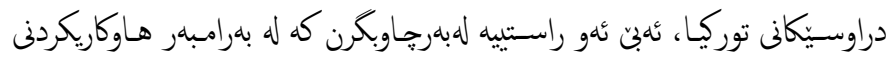

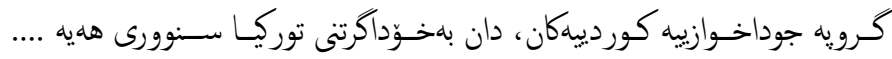

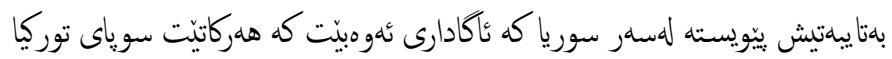

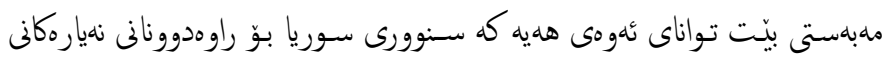

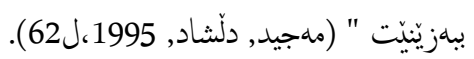

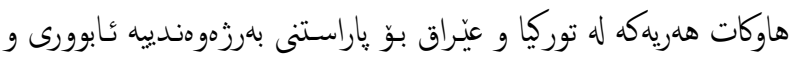

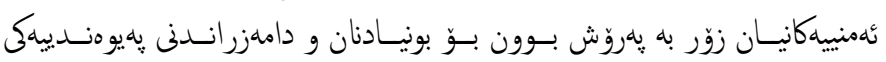

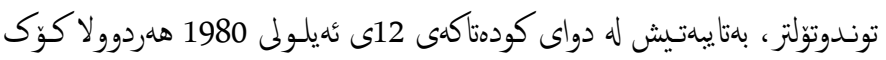

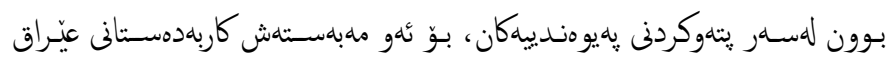

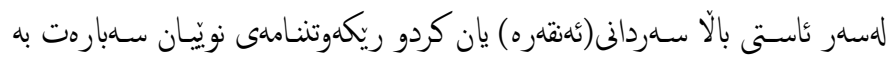

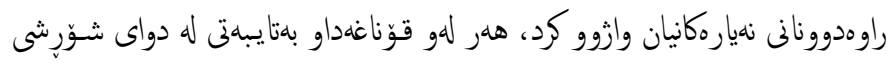

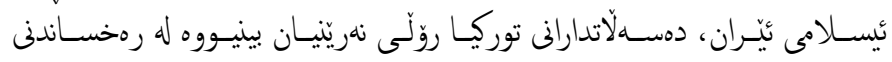

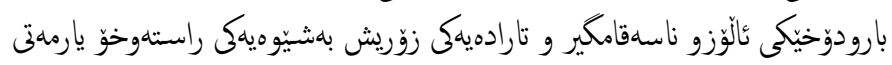

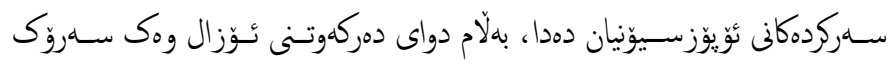

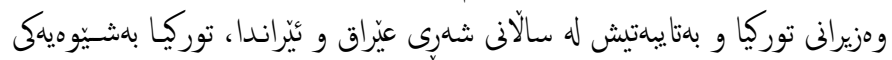

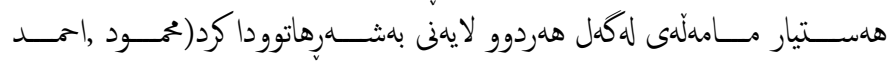

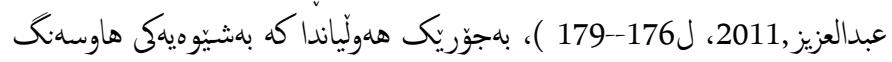

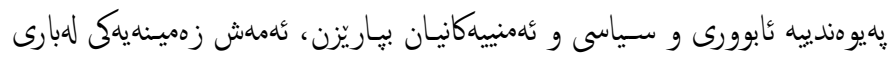

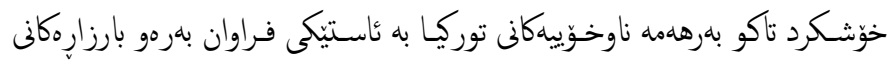

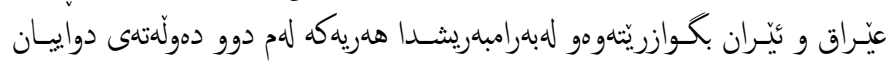

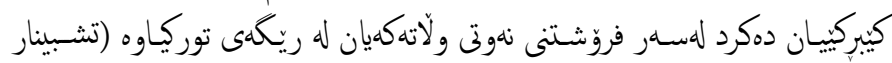

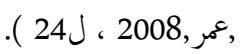

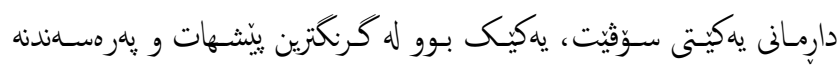

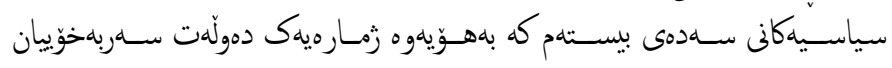

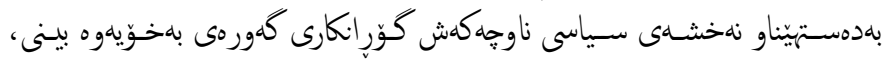

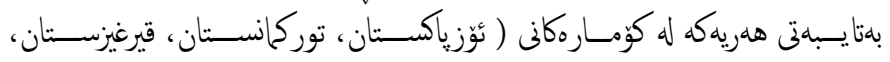

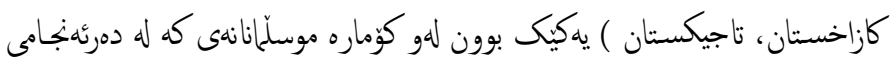

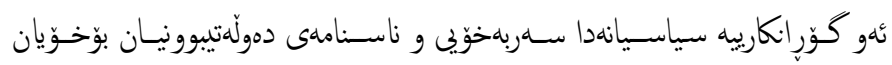

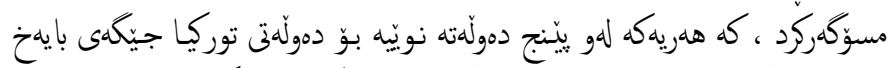

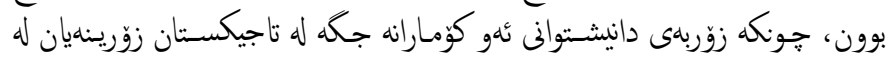

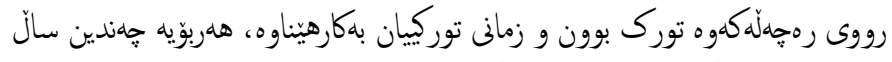

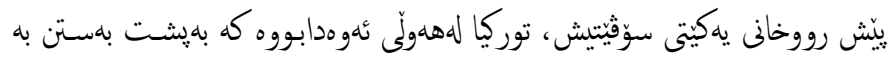


الغالبي,سلوى سعد(2002). العلاقات العثانية الامريكية (1830-1918 ) مكتبة مدبولي ، القاهرة

النعيمي ,عبـدالجبار عبـد مصطفى و آخرون(1993).مهموريات آسـيا الوسطى وقفقاسي الجـذور

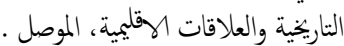

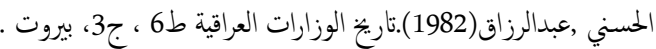

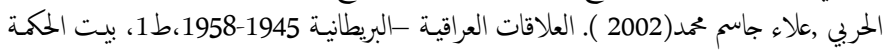
اللنشر، بغداد. روبنس ,فليب(1993). تركيا والشرق الاوسط ،رجمة مخائيل نجم خورى، دار قرطبة للنشر،1ط،

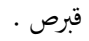
احمد ,فيروز(2000). صنع تركيا الحديثة ، ترجمة .د.سلمان داود و د.حمدى حميد الدورى، بيت المكمة، بغداد.

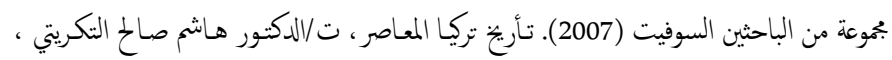
مؤسسة حمدى للطباعة والنشر ، سليماني.

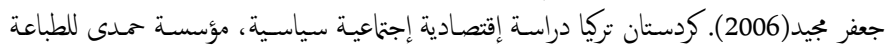

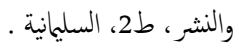
نوالدين,محد(1997). تركيا في زمن المتحول قلق الهوية وصراع الخيارات ، رياض الريس للطباعة نوفل,مشال(2010 ). عودة تركيا إلى الشرق الآتجاهات الجديدة للسياسة التركية، الدراسات العربية

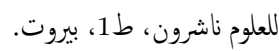

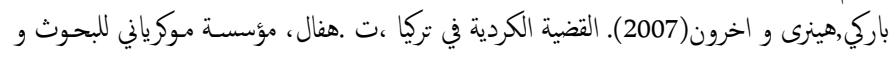
النشر,ط1 باربيل

\section{كوثار كان كوردييةكان :}

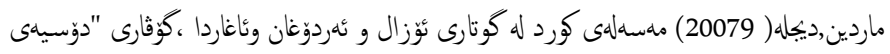

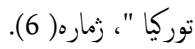

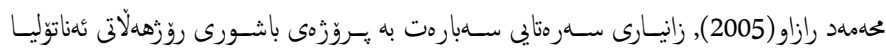
كؤثارى "دوّسيهى توركيا" ، زماره ( 1 ).

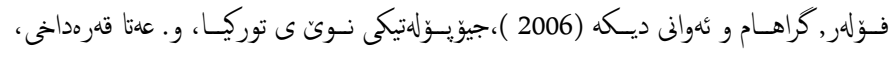

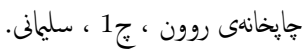

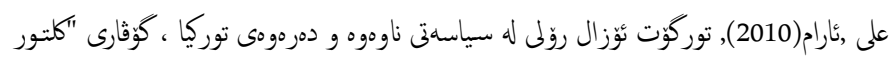

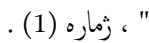

ئنبار , ئنفرايم(2006), هاوكارى ستراتيجى توركيا-اسرائيل ، كؤارى "دوّسيهى توركيا " ، زماره

\section{عهرمبيهكان :}

جاسم رأفراح ناثر (2007 ), توركوت اوزال و مشروع العثليـة الجديدة، مجلة دراسات إقلميـة ،

عدد (6).

شيال ,عزيز جبر (2012), العلاقات العراقية التزكية الواقع والمستقبل، مجلة القادسية للقانون والعلوم

السياسية ،عدد 1، المجلد5 .

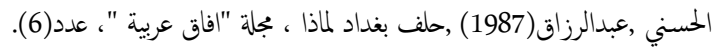

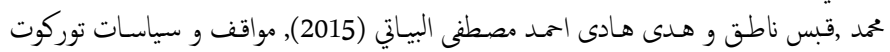

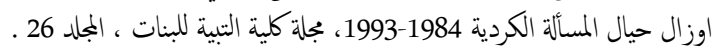
الرئيس التزكي تورغوت أوزال يشرح موقف بلده من حرب الخليج ، مجلة الدراسات المجلة الفلسطينية ،

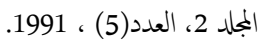

\section{ليستى سهرجاوهكان}

\section{نامدى زانكوّنى}

محمد ,فرح عبدالكريم(2014). النزاع على المياه بين العراق وتركيا 2003-2014، رساله ماجستير

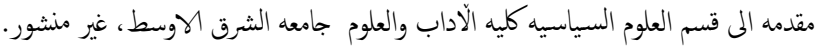

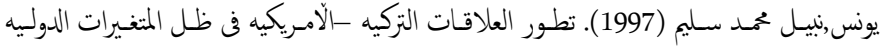

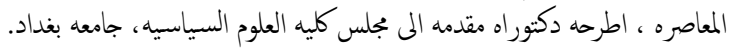

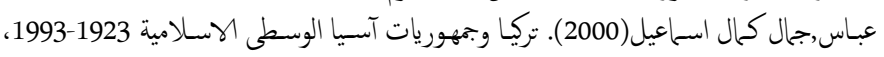
رسالة ماجستير غير منشورة ، جامعة موصل .
كتيّبه كوردييهكان:

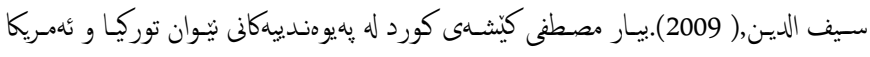

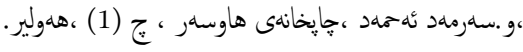

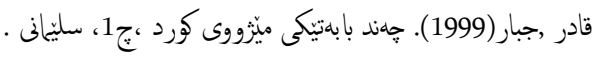

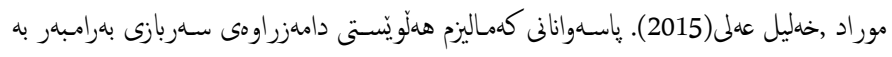

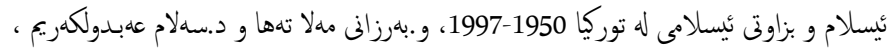

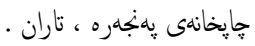

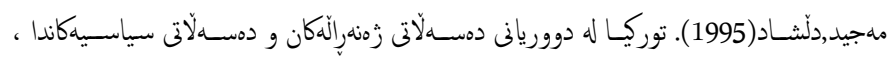

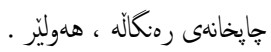

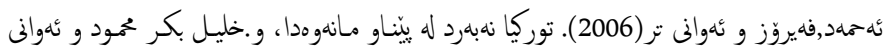
تر، سهنهارى لينكولينهونى ستراتيجى كوردستان ، سليمانى.

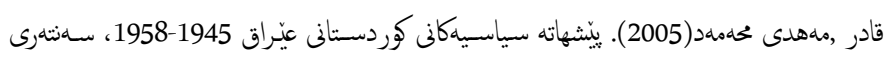

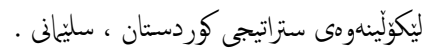

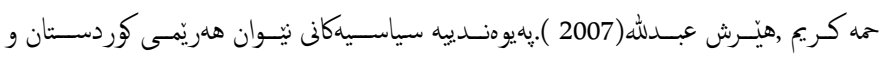

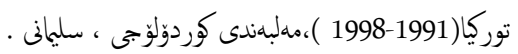

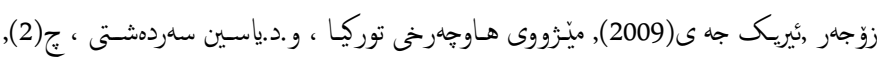
سليمانى.

\section{كتيّبه عهرمبييهكان:}

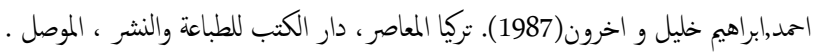

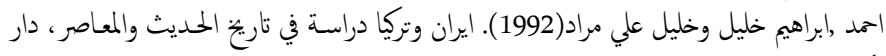

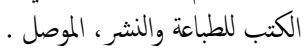

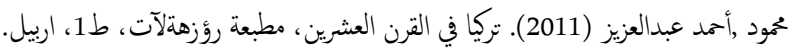

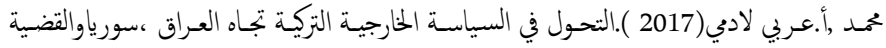

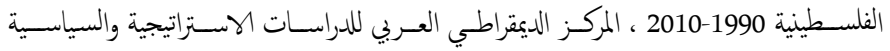
والاقتصادية ، برلين · مبنية

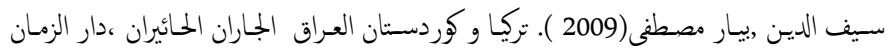

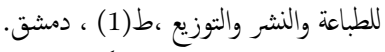
حسن ,جرجيس (1990). تركيا في الاستراتيجية الامريكية بعد سقوط الشاه ، ط1,بدون مكان طبع.

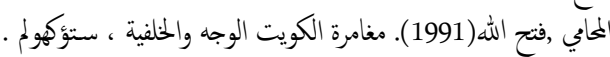

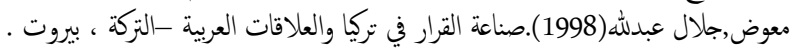

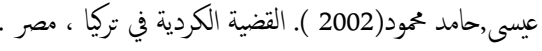




\section{سهرجاوه ثهلكتوزينهكان}

اوغوز ,محم(2010) ,اوزال اقتزح على اوجلان تولي منصب رئيس الوزراء، ترجمه:

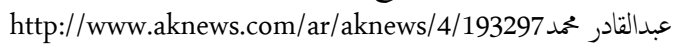

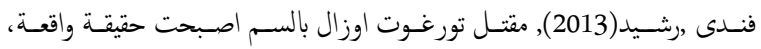
http://www.kdp.info/a/d.aspx?l=14\&a=45123

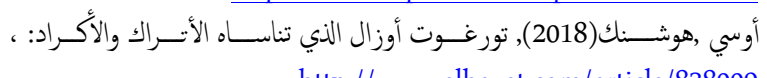
http://www.alhayat.com/article/838009

تشـبينار ,عمر (2018), سياسـات تركيا في الشرق الآوسط بين الكمالية والعثانية

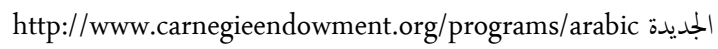
دجلة ,خطيب(2010) ,اوزال اقتح على اوجلان تولي منصب رئيس الوزراء 6http://www.aknews.com/ar/aknews/4/193297

:http://biography.yourdictionary.com7TurgutÖzalFacts2010 